\title{
Etiologia i patogeneza szpiczaka plazmocytowego
}

\section{The etiology and pathogenesis of plasma cell myeloma}

\author{
Elżbieta Iskierka-Jażdżewska ${ }^{1}$, Krzysztof Jamroziak $^{2}$ \\ ${ }^{1}$ Katedra i Klinika Hematologii, Uniwersytet Medyczny, Łódź \\ ${ }^{2}$ Klinika Hematologii, Instytut Hematologii i Transfuzjologii, Warszawa
}

\section{Streszczenie}

Szpiczak plazmocytowy (PCM) jest nowotworowym rozrostem komórek plazmatycznych, w którym wystepuja charakterystyczne objawy uszkodzenia narzqdów, wtórne do procesu nowotworowego. Mimo znacznego postepu w terapii chorych PCM wiedza na temat etiopatogenezy tej choroby pozostaje niekompletna. Do najlepiej udokumentowanych czynników zwiazanych ze zwięsszonym ryzykiem zachorowania na PCM należa wystęowanie gammopatii monoklonalnej o nieokreślonym znaczeniu (MGUS), zaawansowany wiek, pleć męska oraz określona grupa etniczna. Rozwój nowotworu plazmocytowego polega na stopniowej ewolucji od wczesnego i bezobjawowego stadium MGUS, przez objawowy PCM, do końcowej fazy białaczki plazmocytowej. W obecnym modelu patogenezy PCM zaktada się istnienie dwóch odrębnych szlaków inicjujacych transformacje nowotworowa — szlak translokacji z udziatem genów immunoglobulin oraz szlak hiperdiploidii (trisomii). Obok zmian molekularnych $w$ obrębie klonu plazmocytowego kluczowa role $w$ patogenezie PCM odgrywaja interakcje z komórkami mikrośrodowiska szpiku kostnego. Po transformacji nowotworowej, w dalszym etapie progresji PCM, dochodzi do wtórnych zaburzeń molekularnych, które prowadza do stopniowego uniezależnienia się od mikrośrodowiska szpiku kostnego i zazwyczaj zwiększaja agresywność nowotworu. Lepsze poznanie ztożonych mechanizmów patogenetycznych PCM w ostatnich latach budzi nadzieje na poszerzenie możliwości terapeutycznych i dalsza poprawe rokowania $w$ przysztości.

Słowa kluczowe: szpiczak plazmocytowy, etiopatogeneza, MGUS, heterogenność klonalna, mikrośrodowisko szpiku kostnego, szpiczakowe komórki macierzyste

Hematologia 2015; 6, 3: 245-263

\begin{abstract}
Plasma cell myeloma (PCM) is a neoplasm of plasma cells characterized by specific end organ damage. Despite significant progress in the therapy of PCM, knowledge about the etiopathogenesis of this disease remains unsatisfactory. Monoclonal gammopathy of undetermined significance (MGUS), advanced age, male gender and ethnic group belong to best documented factors associated with an increased risk of PCM development. Several stages of PCM evolution from early and asymptomatic MGUS to symptomatic PCM and final stage of plasma cell leukemia were identified. The current model of PCM pathogenesis assumes the existence of two separate pathways initiating neoplastic transformation - the translocations involving immunoglobulin genes and hyperdiploidy (trisomies). Besides molecular changes within atypical plasma cells, interaction with the bone marrow microenvironment plays a key role in the pathogenesis of PCM. After initial transformation,
\end{abstract}

Address for correspondence: Elżbieta Iskierka-Jażdżewska, Katedra i Klinika Hematologii, Uniwersytet Medyczny, ul. Ciołkowskiego 2, 93-510 Łódź, tel. 42689 51 91, faks 4268951 92, e-mail: elaiskierka@gmail.com 
a number of secondary molecular alterations occur at subclonal level leading to gradual independence from bone marrow microenvironment and increase of the aggressiveness of the tumor. It is likely that better understanding of complex mechanisms of PCM pathogenesis will contribute to development of novel therapeutic strategies and further improvement of PCM prognosis in the future

\section{Key words: plasma cell myeloma, etiopathogenesis, MGUS, subclonal heterogeneity, bone marrow microenviroment, myeloma stem cells}

Hematologia 2015; 6, 3: 245-263

\section{Wprowadzenie}

Szpiczak plazmocytowy (PCM, plasma cell myeloma) to nowotwór charakteryzujący się monoklonalnym rozrostem atypowych komórek plazmatycznych oraz określonymi wtórnymi objawami narządowymi. Choroba ta stanowi około $1 \%$ wszystkich nowotworów oraz 10-15\% rozrostów hematologicznych. Średni wskaźnik zachorowalności na PCM w Europie wynosi 4-6 przypadków/100 000 osób/rok.

Rozwój PCM to proces wieloetapowy, który prawdopodobnie zawsze rozpoczyna się bezobjawowym stadium przednowotworowym nazywanym gammopatią monoklonalną o nieokreślonym znaczeniu (MGUS, monoclonal gammopathy of undetermined significance) [1, 2]. Występuje ona w populacji ogólnej bardzo często - u 3-4\% osób po 50. roku życia, jednak w ciagu roku jedynie u $1 \%$ pacjentów $z$ tym rozpoznaniem dochodzi do progresji do objawowego PCM [3, 4]. U części chorych, w procesie ewolucji od MGUS do PCM, występuje dodatkowy, bezobjawowy, etap pośredni określany mianem szpiczaka tlącego się (SMM, smoldering multiple myeloma). Ryzyko progresji do postaci objawowej w SMM wynosi 10\%/ /rok w ciagu pierwszych 5 lat od momentu rozpoznania i następnie maleje [5].

Etiopatogeneza PCM nie została dotychczas w pełni poznana. Jednak sukcesywny rozwój metod badawczych umożliwił w ostatnich latach odkrycie wielu zaburzeń istotnych w procesie rozwoju PCM. Niski potencjał proliferacyjny komórek PCM stanowił pewne ograniczenie $\mathrm{w}$ badaniach klasycznymi metodami cytogenetycznymi. Wyraźny postęp uzyskano po wprowadzeniu badań metodą fluorescencyjnej hybrydyzacji in situ (FISH, fluorescence in situ hybridization), która nie tylko umożliwiła analizę wszystkich atypowych plazmocytów, niezależnie od fazy cyklu komórkowego, ale również przyczyniła się do potwierdzenia obecności zaburzeń chromosomalnych stwierdzanych wcześniej w innych chorobach nowotworowych, a niewidocznych w przypadku klasycznego badania cytogenetycznego [6]. Ponadto w ostatnich latach, dzięki upowszechnieniu badań molekularnych technikami mikromacierzy DNA/RNA i wydajnych metod sekwencjonowania następnej generacji (NGS, next generation sequencing), dokonano dalszych interesujących odkryć dotyczących mechanizmów patogenetycznych i architektury wewnątrzklonalnej PCM [7, 8].

Mimo coraz lepszego rozumienia patogenezy PCM dotychczasowy postęp w terapii tego nowotworu był jednak głównie wynikiem wieloletnich badań empirycznych nad zastosowaniem nowych metod leczenia. Spektakularna poprawa rokowania, w postaci podwojenia mediany oczekiwanego czasu przeżycia, jest przede wszystkim konsekwencją opracowania i wprowadzenia do terapii dwóch nowych klas leków - inhibitorów proteasomu (IP) i leków immunomodulujących (IMiD, immunomodulatory drugs). Decydujący wpływ IP i IMiD na obserwowane wydłużenie życia chorych potwierdzono zarówno w randomizowanych badaniach klinicznych, jak i w dużych analizach epidemiologicznych [9-12]. Niedawna rejestracja kolejnych generacji IMiD (pomalidomid) i IP (karfilzomib) [13, 14], zaawansowane badania nad nowymi obiecującymi cząsteczkami (np. daratumumab) [15], a także ciągły postęp w poznawaniu mechanizmów odpowiedzialnych za rozwój i progresję PCM budzą uzasadnioną nadzieję na dalszą poprawę rokowania.

\section{Zarys etiopatogenezy PCM}

Mimo znacznego w ostatnich latach postępu technologicznego, który istotnie poszerzył możliwości poznawania cytogenetycznych i molekularnych zaburzeń w komórce nowotworowej, wiedza na temat etiopatogenezy PCM pozostaje niekompletna. Podobnie jak w przypadku większości innych nowotworów, w rozwoju PCM główną rolę odgrywa interakcja między określonymi czynnikami środowiskowymi oraz specyficzną predyspozycją genetyczną. Wyniki badań asocjacyjnych całego genomu (GWAS, genome-wide association study) umożliwiły identyfikację części wariantów 
genetycznych odpowiedzialnych za zwiększone ryzyko rozwoju MGUS i PCM $[16,17]$.

Zgodnie $z$ aktualnymi poglądami na patogenezę PCM składa się kilka etapów prowadzących od przednowotworowego stadium MGUS do końcowej fazy niekontrolowanej proliferacji atypowych komórek plazmatycznych, które uzyskały niezależność od mikrośrodowiska szpiku kostnego. Za czynnik inicjujący rozwój PCM uważa się przewlekłą stymulację antygenową nasilającą podziały i różnicowanie komórek układu immunologicznego [18-21]. Taka dysfunkcyjna stymulacja powoduje zwiększone ryzyko przypadkowego błędu genetycznego (inicjującego uszkodzenia onkogennego), ale także zwiększa ryzyko przetrwania i ucieczki klonu nowotworowego spod kontroli mechanizmów obronnych.

Inicjujący defekt molekularny zachodzi na drodze jednego $z$ dwóch alternatywnych szlaków onkogennych - hiperdiploidii lub translokacji z udziałem wzmacniaczy genów immunoglobulinowych. Wydaje się, że wystąpienie tych zdarzeń inicjujących w prawidłowej komórce B, podczas różnicowania w ośrodkach rozmnażania grudki chłonnej, może doprowadzić do transformacji nowotworowej i rozwoju przednowotworowego stadium MGUS. Następnie, u części chorych, dalsza stymulacja immunologiczna ze strony mikrośrodowiska szpiku oraz wtórne zmiany genetyczne prowadzą do przejścia MGUS, kolejno, do fazy SMM i następnie objawowego PCM. W dalszych etapach ewolucji nowotworu plazmocytowego, wskutek wtórnych zmian genetycznych, mogą wystąpić stadium PCM pozaszpikowego i końcowa faza w postaci wtórnej białaczki plazmocytowej [22]. Poniżej bardziej szczegółowo omówiono poszczególne elementy istotne w etiopatogenezie PCM.

\section{Charakterystyka komórek prekursorowych i komórek macierzystych PCM}

W procesie prawidłowej odpowiedzi immunologicznej, w pierwszym niezależnym od antygenu etapie dojrzewania limfocytu B odbywającym się w szpiku kostnym, zachodzą rearanżacje genów immunoglobulinowych - początkowo łańcucha ciężkiego i następnie lekkiego. W przypadku uzyskania produktywnych rearanżacji powstają dojrzałe limfocyty B z powierzchniową ekspresją immunoglobulin klasy IgM kappa lub IgM lambda, które następnie zasiedlają wtórne narządy limfatyczne. W kolejnej fazie w ośrodkach rozmnażania grudek chłonnych wtórnych narządów limfatycznych za- chodzi etap wtórnej odpowiedzi immunologicznej, który zależy od antygenu. Polega on na zwiększeniu powinowactwa receptorów immunoglobulinowych do antygenu dzięki dodatkowym mechanizmom warunkującym różnorodność genetyczną, czyli hipermutacji somatycznej (SHM, somatic hypermutation) i rekombinacji klas (CSR, class switch recombination). Komórki B, które przeszły te procesy, stają się komórkami pamięci lub powracają do szpiku jako długożyjące komórki plazmatyczne [23].

Dotychczasowe wyniki badań wskazują, że właśnie długożyjące, postgerminalne komórki plazmatyczne są najbliższe pod względem morfologicznym, immunofenotypowym i genetycznym atypowym plazmocytom PCM. Podobnie jak prawidłowe długo żyjące plazmocyty, nowotworowe komórki PCM charakteryzują się znaczną SHM, brakiem ekspresji IgM w ponad 99\% przypadków oraz silną zależnością od mikrośrodowiska szpiku kostnego [24]. Zatem komórki PCM, w przeciwieństwie do krótkożyjących plazmocytów generowanych podczas pierwotnej odpowiedzi immunologicznej, ukończyły zależny od antygenu proces SHM. Ponadto większość komórek PCM produkuje białko klasy IgG lub IgA, co świadczy o zakończeniu procesu CSR. Również natura niektórych zmian onkogennych obserwowanych u chorych na PCM, szczególnie translokacji obejmujących geny łańcucha ciężkiego immunoglobulin (IGH, immunoglobulin heavy chain), wskazuje, że mogą one zachodzić podczas SHM lub CSR [25, 26].

Jednak, w odróżnieniu od prawidłowych plazmocytów, komórki PCM zachowują niski potencjał proliferacyjny. Ponadto cechują się pewnymi odmiennościami w ekspresji antygenów powierzchniowych. Zdrowe plazmocyty charakteryzują się immunofenotypem CD38+CD138+CD19+CD45+CD56-, natomiast nowotworowe plazmocyty PCM, SMM i MGUS odróżniają: brak ekspresji antygenu CD19 (90\% przypadków), brak lub niska ekspresja antygenu CD45 (99\% przypadków) oraz obecność antygenu CD56 (70\% przypadków) [27]. Nie jest wykluczone, że istnieje niewielki odsetek prawidłowych plazmocytów o fenotypie typowym dla PCM, które mogłyby być punktem wyjściowym dla transformacji nowotworowej, jednak ich dotychczas nie zidentyfikowano. Bardziej prawdopodobnym wyjaśnieniem obserwowanych różnic jest więc uruchomienie odpowiedniego programu epigenetycznego w procesie transformacji nowotworowej, którego jedną $z$ konsekwencji jest zmiana ekspresji powierzchniowych markerów.

Na podstawie przeprowadzonych doświadczeń wydaje się, że tylko niewielka frakcja plazmocytów 
PCM wykazuje zdolność do odnawiania guza po przeszczepieniu w modelu mysim [28]. Dotychczas w wielu procesach rozrostowych wykazano obecność subpopulacji nowotworowych komórek macierzystych (CSC, cancer stem cells), które, niezależnie od rodzaju markerów na swojej powierzchni, charakteryzowały się zdolnością do proliferacji, możliwością samoodnawiania oraz opornością na stosowane terapie [29-31]. Obecnie uważa się, że takie nowotworowe komórki macierzyste równiez stanowią podstawę rozwoju PCM. Podstawą tej koncepcji jest ogólny model, w którym nowotwór porównuje się $z$ systemem krwiotwórczym $z$ zachowaną asymetryczną równowagą dwóch rodzajów komórek, gdzie niewielka liczebnie grupa CSC pełni podtrzymującą rolę względem ogólnej populacji komórek nowotworowych.

Prawidłowe komórki B, dzięki zdolności samoodnawiania, podtrzymują długotrwałą pamięć immmunologiczną, dlatego - zgodnie $z$ jedną $z$ hipotez - to właśnie te komórki stanowią podłoże dla macierzystych komórek szpiczakowych. W jednym $z$ przeprowadzonych badań wykazano, że spośród proliferujących komórek szpiczakowych CD138- jedynie komórki z ekspresją CD19 i CD27, czyli antygenów typowych dla limfocytów B pamięci, były zdolne do tworzenia kolonii $\mathrm{w}$ warunkach in vitro [32]. Jednocześnie zaobserwowano, że wyizolowane $z$ krwi obwodowej chorych na PCM komórki o fenotypie CD19+CD27+CD138- po przeszczepieniu myszom $z$ NOD/SCID (non-obese diabetic/severe combined immunodeficiency) spowodowały znaczący wzrost dojrzałych, szpiczakowych komórek CD138+ wydzielających białko monoklonalne [32]. Co ciekawe, w innych badaniach wykazano potencjalną klonogenną aktywność w komórkach plazmatycznych bez ekspresji antygenów typowych dla limfocytów B. Plazmocyty o fenotypie CD138-CD19-CD38+ pobrane od chorych na PCM i wszczepione myszom z SCID wywoływały pełnoobjawową postać PCM. Co więcej, komórki $z$ antygenem CD138 również indukowały rozwój choroby, ale znacznie wolniej względem komórek CD138- [33]. Rozbieżne wyniki przeprowadzonych dotychczas analiz nie pozwalają obecnie na jednoznaczne określenie fenotypu macierzystych komórek szpiczakowych.

\section{Predyspozycja genetyczna do zachorowania na PCM}

Oprócz omówionych niżej stadiów prekursorowych MGUS i SMM do najlepiej udokumentowanych parametrów związanych ze zwiększonym ryzykiem zachorowania na PCM należą zaawansowany wiek, płeć męska oraz grupa etniczna. Większość chorych na PCM jest diagnozowana w wieku powyżej 65 lat, a zachorowania wśród osób przed 35. rokiem życia stanowią mniej niż $1 \%$ przypadków PCM [34]. W odniesieniu do płci zachorowalność na PCM jest około 1,5 razy większa wśród mężczyzn [35], co może świadczyć między innymi o związku $z$ regulacją hormonalną. Obserwuje się również znaczne różnice etniczne. Ryzyko PCM jest około 2-krotnie wyższe u Amerykanów pochodzenia afrykańskiego niż u Amerykanów rasy kaukaskiej i znacznie niższe u Azjatów [36].

Dotychczas zgromadzono dużą ilość danych przemawiających za istotnym znaczeniem predyspozycji genetycznej w etiopatogenezie PCM. Analizy przypadków PCM u bliźniąt jedno- i dwujajowych, a także dane na temat agregacji rodzinnej zachorowań na PCM, wyraźnie wskazują na znaczny genetyczny komponent skłonności do zachorowania. Ryzyko wystąpienia choroby jest prawie 4-krotnie zwiększone u krewnych pierwszego stopnia chorych na PCM [37, 38]. Podobnie jak w przypadku większości nowotworów genetyczne tło predyspozycji do PCM jest wielogenowe i wynika ze wspólnych oddziaływań wielu częstych wariantów allelicznych związanych $z$ niewielkim podwyższeniem ryzyka. Wskazują na to zarówno liczne badania asocjacyjne obejmujące polimorfizmy pojedynczych genów kandydatów, jak i wyniki badań GWAS $[16,17]$. W badaniach genów kandydatów wśród wariantów polimorficznych związanych $z$ ryzykiem zachorowania na PCM wyróżniono wybrane polimorfizmy genów cytokin (np. $I L-1, I L-6, T N F)$ [39-41], czynników wzrostu, adhezyn i szlaków sygnałowych (TRAF, IGF-1, SERPINE) [42, 43], genów związanych z odpowiedzią na uszkodzenie DNA, mechanizmami naprawczymi i regulacją apoptozy oraz genów związanych $z$ transportem i metabolizmem ksenobiotyków oraz toksyn endogennych [44, 45]. Powyższe zmiany genetyczne prawdopodobnie odgrywają rolę w powiązaniu $z$ ekspozycją środowiskową, powodując na przykład wzmożoną odpowiedź cytokinową $\mathrm{w}$ przebiegu infekcji wirusowej. Jednocześnie jednak wiadomo, że badania farmakogenetyczne służące analizie polimorfizmów genów kandydatów są obarczone wysokim ryzykiem wyników fałszywie dodatnich. $Z$ tego powodu u chorych na PCM przeprowadzono dotychczas dwa badania GWAS [16, 17], w których również wskazano na warianty genetyczne związane $z$ predyspozycją do PCM. W obu przeprowadzonych analizach 
Tabela 1. Warianty genetyczne związane z ryzykiem zachorowania na szpiczaka plazmocytowego (PCM) w badaniach GWAS (na podstawie $[16,17]$ )

Table 1. Genetic variation influences plasma cell myeloma (PCM) risk in genome-wide association study (GWAS) (based on $[16,17])$

\begin{tabular}{|c|c|c|c|c|}
\hline Badanie & Wariant & Znaczenie & OR & $p$ \\
\hline \multirow[t]{3}{*}{$\begin{array}{l}\text { Genotypowanie DNA u } 1675 \\
\text { chorych na PCM i } 5903 \text { osób } \\
\text { z grupy kontrolnej (Broderick } \\
\text { i wsp. 2011) }\end{array}$} & $\begin{array}{c}3 p 22.1 \\
(\text { rs1052501, ULK4) }\end{array}$ & $\begin{array}{l}\text { Gen ULK4 koduje kinazę serynowo- } \\
\text {-treoninową } \\
\text { Kompleks Atgl-ULK jest kluczowym } \\
\text { regulatorem autofagii pośredniczo- } \\
\text { nej przez szlak sygnałowy mTOR }\end{array}$ & 1,32 & $7,47 \times 10^{-9}$ \\
\hline & $\begin{array}{c}\text { 7p15.3 } \\
(\mathrm{rs} 4487645, C D C A 7 L)\end{array}$ & $\begin{array}{l}\text { W wyniku ekspresji genu CDCA7L } \\
\text { powstaje białko reagujące z białkiem } \\
\text { MYC, z którym wiąże białko p75 } \\
\text { i tym samym nasila procesy } \\
\text { transformacji komórek }\end{array}$ & 1,38 & $3,33 \times 10^{-15}$ \\
\hline & $\begin{array}{c}2 \mathrm{p} 23.3 \\
(\mathrm{rs} 6746082, D T N B)\end{array}$ & $\begin{array}{l}\text { Nie znaleziono wpływu } \\
\text { polimorfizmu w genie DTNB } \\
\text { na ryzyko rozwoju PCM }\end{array}$ & 1,29 & $1,22 \times 10^{-7}$ \\
\hline \multirow[t]{4}{*}{$\begin{array}{l}\text { Genotypowanie DNA u } 4692 \\
\text { chorych na PCM i } 10990 \text { osób } \\
\text { z grupy kontrolnej (Chubb D. } \\
\text { i wsp. } 2013 \text { ). }\end{array}$} & $\begin{array}{c}\text { 3q26.2 } \\
\text { (rs10936599, MYNN, } \\
\text { TERC) }\end{array}$ & $\begin{array}{l}\text { Ekspresja genu TERC stanowi skła- } \\
\text { dową część telomerazy RNA. W PCM } \\
\text { zaobserwowano reaktywację telo- } \\
\text { merazy oraz wydłużanie krótszych } \\
\text { telomerów poprzez działanie tego } \\
\text { enzymu jako jeden z mechanizmów } \\
\text { odpowiedzialnych za rozwój choroby }\end{array}$ & 1,26 & $8,70 \times 10^{-14}$ \\
\hline & $\begin{array}{c}6 \mathrm{p} 21.33 \\
(\mathrm{rs} 2285803, \text { PSORS1C2 } \\
\text { CCHCR1, CDSN, TCF19 i } \\
\text { POU5F1) }\end{array}$ & $\begin{array}{l}\text { Dotychczas nie udowodniono istot- } \\
\text { nej roli genu POU5F1 w patogenezie } \\
\text { PCM, ale gen ten koduje białko OCT3 } \\
\text { regulujące pluripotencjalność } \\
\text { komórek oraz ekspresję genów } \\
\text { specyficznych tkankowo }\end{array}$ & 1,19 & $9,67 \times 10^{-11}$ \\
\hline & $\begin{array}{c}17 p 11.2 \\
(r s 4273077, T N F R S F 13 B)\end{array}$ & $\begin{array}{c}\text { TNFRSF13B (inaczej gen } T A C I \text { ) to gen } \\
\text { należący do superrodziny recepto- } \\
\text { rów czynnika martwicy nowotworów } \\
\text { będący kluczowym } \\
\text { regulatorem funkcji limfocytów B } \\
\text { i T, niezbędny do rozwoju komórek B } \\
\text { Polimorfizmy w obrębie tego genu } \\
\text { stanowią czynnik ryzyka dla selek- } \\
\text { tywnego niedoboru immunoglobulin } \\
\text { z towarzyszącą limfoproliferacją }\end{array}$ & 1,26 & $7,67 \times 10^{-9}$ \\
\hline & $\begin{array}{c}22 q 13.1 \\
(\mathrm{rs} 877529, \mathrm{CBX} 7)\end{array}$ & $\begin{array}{c}\text { Grupa białek będących wynikiem } \\
\text { ekspresji genu CBX7 współtworzy } \\
\text { mechanizm regulujący przeznaczenie } \\
\text { komórek w czasie ich rozwoju oraz } \\
\text { bierze udział w kontroli wzrostu } \\
\text { i różnicowania }\end{array}$ & 1,23 & $7,63 \times 10^{-16}$ \\
\hline
\end{tabular}

mTOR (mammalian target of rapamycin kinase) — ssaczy cel rapamycyny

łącznie zaobserwowano siedem polimorfizmów pojedynczego nukleotydu związanych ze zwiększonym ryzykiem wystąpienia PCM. W badaniu Brodericka i wsp. [16] dowiedziono, że wystąpienie odpowiednich wariantów genów w loci $3 \mathrm{p} 22.1$, 7 p15.3 i 2 p.23.3 jest odpowiedzialne za około $4 \%$ całkowitego rodzinnego ryzyka zachorowania na PCM. Z kolei w pracy Chubba i wsp. [17] cztery polimorfizmy genów zlokalizowanych na chromo- somach 3q26.2, 6p21.33, 17p11.2 i 22q13.1 stanowią łącznie około $9 \%$ rodzinnej predyspozycji do rozwoju PCM. Najważniejsze wyniki tych badań przedstawiono w tabeli 1 . Warto jednak pamiętać, że równiė̇ ta metoda badawcza jest obarczona dużym ryzykiem błędu, wynikającym chociażby $z$ relatywnie niewielkiej zachorowalności na PCM w ogólnej populacji oraz różnic w częstości alleli w poszczególnych grupach etnicznych. 


\section{Znaczenie czynników środowiskowych w rozwoju PCM}

Bardzo interesujące są wyniki badań wskazujące na zwiększoną zachorowalność na PCM u osób, które przebyły choroby charakteryzujące się przewlekłą, wzmożoną aktywacją układu immunologicznego. Zwiększone ryzyko wystąpienia PCM dotyczy w szczególności chorób autoimmunizacyjnych (różnych, ale ostatnio zwraca się szczególną uwagę na niedokrwistość Addisona-Biermera), przewlekłych chorób zapalnych (kłębuszkowe zapalenie nerek, osteoartritis) oraz niektórych infekcji bakteryjnych i wirusowych (zapalenie pluc, zapalenie opon mózgowo-rdzeniowych, wirusowe zapalenie wątroby typu C, zakażenie ludzkim wirusem niedoboru odporności [HIV, human immunodeficiency virus]/zespół nabytego niedoboru odporności [AIDS, acquired immune deficiency syndrom], zakażenia wirusami herpes-zoster i wirusem polio) [46]. Obserwacje te mogą dowodzić istotnego znaczenia nieprawidłowej regulacji immunologicznej w patogenezie PCM, co dobrze udokumentowano w niektórych innych typach chłoniaków. Podobnie świadczą dane wskazujące na pobudzenie odpowiedzi cytokinowej mikrośrodowiska, która poprzedza rozpoznanie PCM. Stwierdzono między innymi zwiększone stężenia takich cytokin, jak insulinopodobny czynnik wzrostu 1 (IGF-1, insulin-like growth factor 1) i interleukina 6 (IL-6), kilka lat przed rozpoznaniem PCM [47]. Wydzielana przez komórki dendrytyczne szpiku IL-6 jest podstawowym czynnikiem wzrostu prawidłowych komórek plazmatycznych.

Wśród innych czynników środowiskowych związanych $z$ zachorowaniem na PCM wymienia się również otyłość oraz dietę zawierającą małą ilość ryb lub warzyw. Rolę otyłości poparto w niektórych wynikach badań biologicznych sugerujących istotny udział lipidów w patogenezie PCM [19, 48]. Brakuje natomiast przekonujących danych na temat udziału typowych czynników kancerogennych, które są istotne $\mathrm{w}$ etiologii wielu innych typów nowotworów. Przykładowo, badania epidemiologiczne, w których analizowano ekspozycję na toksyny środowiskowe i zawodowe u chorych na PCM, dostarczyły kontrowersyjnych obserwacji. Chociaż w części z nich ryzyko zachorowania na PCM powiązano $z$ ekspozycją na pestycydy, rozpuszczalniki organiczne, farby do włosów czy gumę, to jednak $\mathrm{w}$ innych pracach tych zależności nie potwierdzono [49-52]. Podobnie rozbieżne obserwacje dotyczyły związku zachorowalności z narażeniem na radiację, paleniem tytoniu lub spożywaniem alkoholu [53,
54]. Dlatego wyodrębnienie kancerogenów istotnych w inicjacji procesu rozwoju PCM wymaga dalszych badań.

\section{Bezobjawowe stadia prekursorowe PCM}

Wprawdzie MGUS jest stadium prekursorowym poprzedzającym wystąpienie PCM u wszystkich chorych, ale ze względu na brak objawów klinicznych najczęściej pozostaje nierozpoznana. Choroba ta jest definiowana jako występowanie immunoglobulinowego białka monoklonalnego w surowicy krwi w stężeniu poniżej $30 \mathrm{~g} / 1$ oraz obecność nacieku klonalnych plazmocytów nieprzekraczającego 10\% komórek szpiku kostnego i brak objawów narządowych typowych dla PCM. Stadium przednowotworowym PCM może być tak zwana MGUS-nie IgM, w której białko monoklonalne stanowią immunoglobuliny klas IgG lub IgA, oraz MGUS łańcuchów lekkich, w której jest produkowany wyłącznie lańcuch lekki kappa lub lambda. Natomiast MGUS z białkiem monoklonalnym klasy IgM zazwyczaj ewoluuje w kierunku chłoniaka limfoplazmocytowego, przewlekłej białaczki limfocytowej lub rzadziej innych typów chłoniaków. Ryzyko ewolucji MGUS do PCM wynosi około 1\%/rok, co oznacza, że nowotwór ten nie rozwinie się u zdecydowanej większości pacjentów z MGUS. U części chorych w czasie stopniowej transformacji MGUS do PCM obserwuje się stadium pośrednie - SMM, które obecnie jest definiowane przede wszystkim jako występowanie nacieku klonalnych plazmocytów w odsetku w zakresie 10-60\% komórek szpiku oraz brak objawów narządowych typowych dla PCM [55]. W SMM ryzyko progresji do postaci objawowej jest wyższe niż w MGUS i wynosi $10 \% /$ /rok w ciągu pierwszych 5 lat od rozpoznania [56].

Wstępny etap choroby jest prawdopodobnie konsekwencją przewlekłej stymulacji antygenowej i polega na unieśmiertelnieniu plazmocytów pełniących rolę macierzystych komórek szpiczakowych, które odpowiadają za tworzenie licznych łagodnych klonów komórek plazmatycznych. Następnie, prawdopodobnie wskutek przypadkowego błędu genetycznego, dochodzi do aktywacji onkogenu, najczęściej przy udziale różnych translokacji obejmujących sekwencje wzmacniające ekspresję w obrębie genów IGH lub hiperdiploidii, i rozwija się MGUS [57, 58].

W kolejnym etapie u niektórych chorych na MGUS dochodzi do dalszej proliferacji i ekspansji klonu nowotworowego, co najpierw objawia się jako SMM, a następnie PCM [59, 60]. Ze względu 
na fakt, że transformacja MGUS do PCM występuje u niewielkiego odsetka pacjentów, niezwykle istotne wydaje się poszukiwanie czynników odpowiedzialnych za tę progresję.

\section{Molekularne szlaki transformacji nowotworowej PCM}

Obecny model onkogenezy PCM (ryc. 1) obejmuje dwa odrębne, inicjujące transformację nowotworową, szlaki molekularne - szlak translokacji $z$ udziałem genów immunoglobulin oraz szlak hiperdiploidii (trisomii). Hiperdiploidia, obecna u około $55 \%$ chorych, polega na występowaniu charakterystycznych trisomii określonych chromosomów nieparzystych $(3,5,7,9,11,15,19,21)[57,61,62]$. Uważa się, że trisomie te są najprawdopodobniej konsekwencją nieprawidłowości w procesie metafazy, jednak ich szczegółowa rola w rozwoju PCM nie jest wyjaśniona. Drugi pod względem częstości typ inicjującego defektu onkogennego dotyczy pierwotnych translokacji między locus genu $I G H$ lub znacznie rzadziej genów łańcuchów lekkich (IGL, immunoglobulin light chain) a różnymi onkogenami, przy czym część partnerów translokacji jest powtarzalna [63]. Pierwotne translokacje wzajemne z zaangażowaniem genów immunoglobulinowych prawdopodobnie powstają wskutek błędów w czasie procesów SHM i CSR w ośrodkach rozmnażania. Translokacje obejmujące locus 14q32 genu IGH lub jedno $\mathrm{z}$ loci genów łańcuchów lekkich $\operatorname{IgL}(\kappa, 2 \mathrm{p} 12$ lub $\lambda, 22 q 11)$ stwierdza się u 40-50\% chorych na PCM. W przeprowadzonych w ostatnim czasie badaniach w dużych grupach chorych wykazano, że występowanie translokacji $I G H$ zwiększa się wraz ze stopniem zaawansowania choroby; obserwuje się je u około $50 \%$ chorych na MGUS i SMM, 55-70\% chorych na objawowy PCM, 85\% chorych na białaczkę plazmocytową i u ponad $90 \%$ pacjentów $z$ chorobą pozaszpikową $[64,65]$. $\mathrm{W}$ podobny sposób translokacje obejmujące gen $\operatorname{IgL}$ występują u około $10 \%$ chorych na MGUS lub SMM i częściej - u 15-20\% — w objawowych fazach PCM [66].

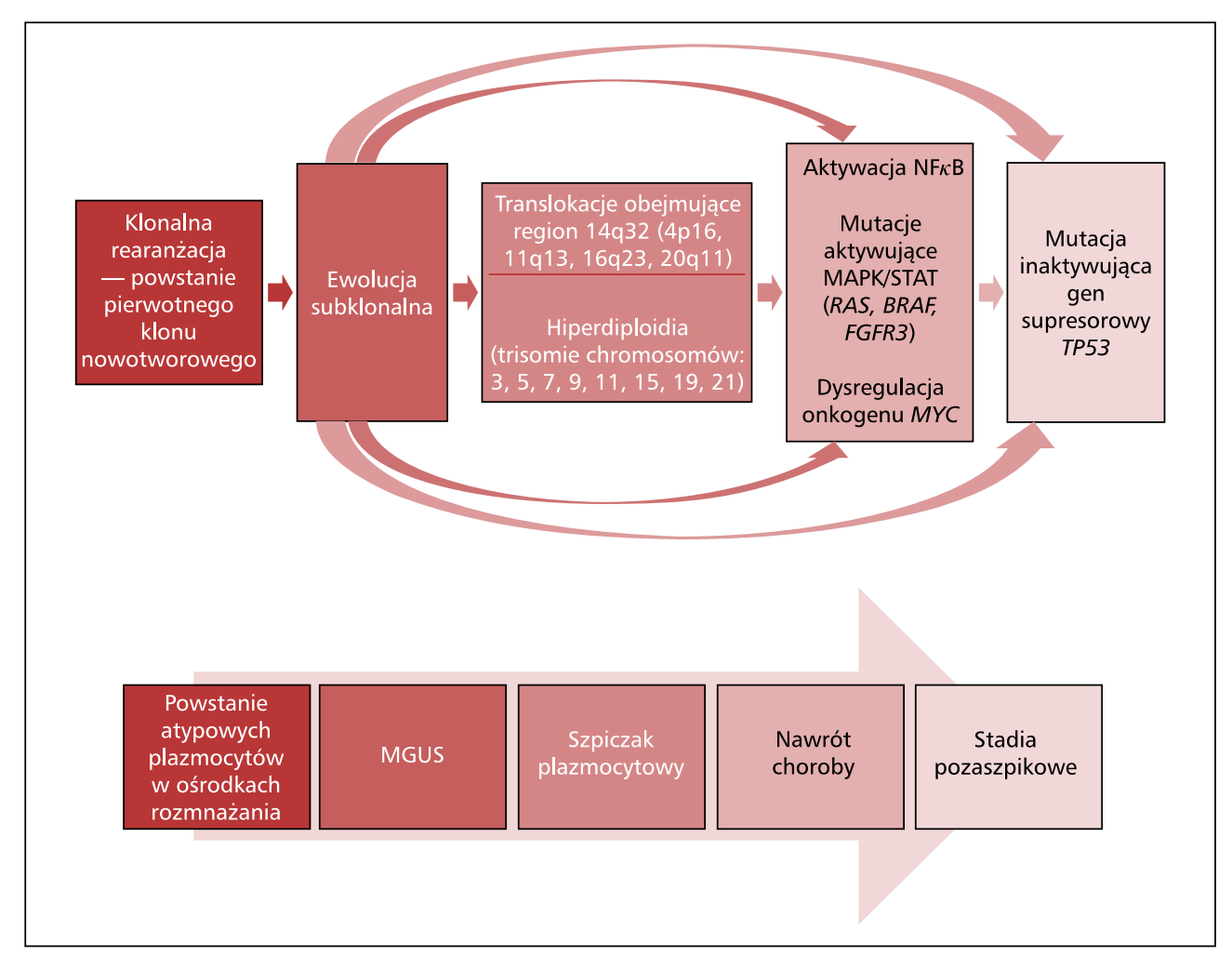

Rycina 1. Model onkogenetyczny w szpiczku plazmocytowym (na podstawie [30]); NF $\kappa$ B - czynnik jądrowy $\kappa$ B; MAPK — kinaza białkowa aktywowana mitogenem; STAT — transduktor sygnału i aktywator transkrypcji; MGUS — gammopatia monoklonalna o nieokreślonym znaczeniu

Figure 1. Oncogenetic model in plasma cell myeloma (based on [30]); NF $\kappa$ B - nuclear factor $\kappa$ B; MAPK - mitogen-activated protein kinase; STAT — signal transducer and activator of transcription; MGUS — monoclonal gammopathy of undetermined significance 
Tabela 2. Aberracje chromosomowe związane z niekorzystnym rokowaniem u chorych na szpiczaka plazmocytowego Table 2. Chromosomal aberrations associated with poor prognosis in patients with plasma cell myeloma

\begin{tabular}{|c|c|c|c|c|}
\hline Aberracja & $\begin{array}{c}\text { Locus/zaangażowane } \\
\text { geny }\end{array}$ & Mechanizm & $\begin{array}{c}\text { Metoda } \\
\text { wykrywania }\end{array}$ & $\begin{array}{l}\text { Częstość występowania } \\
\text { oceniana metodą FISH (\%) }\end{array}$ \\
\hline$t(4 ; 14)(p 16 ; q 32)^{*}$ & $\begin{array}{c}\text { (4p16)/FGFR3 i } M M S E T \\
(14 q 32) / / G H\end{array}$ & $\begin{array}{l}\text { Pośrednio } \\
\uparrow C C N D 2\end{array}$ & FISH & $11-15$ \\
\hline$t(14 ; 16)(q 32 ; q 23)$ & $\begin{array}{c}(16 q 23) / C-M A F-c z y n n i k \\
\text { transkrypcyjny } \\
(14 q 32) / / G H\end{array}$ & $\uparrow C C N D 2$ & FISH & $3-5$ \\
\hline$t(14 ; 20)(q 32 ; q 11)$ & $\begin{array}{c}(20 q 11) / M A F-B-\text { czynnik } \\
\text { transkrypcyjny } \\
(14 q 32) / / G H\end{array}$ & $\uparrow C C N D 2$ & $\begin{array}{c}\mathrm{FISH} \\
\mathrm{CC}\end{array}$ & $1,5-2$ \\
\hline Amplifikacja 1q & $(1 q 21) / C K S 1 B$ i/lub inne & $\begin{array}{l}\text { Udział w kontroli cyklu } \\
\text { komórkowego za pośred- } \\
\text { nictwem CDK i p27 } \\
\text { Anomalia wtórna }\end{array}$ & $\begin{array}{l}\text { FISH } \\
\text { CC }\end{array}$ & $35-50$ \\
\hline $\operatorname{del}(17)(p 13)$ & $(17 p 13) / T P 53$ & $\begin{array}{l}\text { Dysfunkcja czynnika } \\
\text { transkrypcyjnego p53 } \\
\text { Anomalia wtórna }\end{array}$ & $\begin{array}{l}\text { FISH } \\
\text { CC }\end{array}$ & $5-10$ \\
\hline $13 / \operatorname{del}(13 q)^{* *}$ & $(13 q 14) / R B 1$ & $\begin{array}{c}\text { Często skojarzona z t(4;14) } \\
(94 \%) / t(14 ; 16)(73 \%) \\
\text { Anomalia wtórna }\end{array}$ & $\begin{array}{c}\mathrm{FISH} \\
\mathrm{CC}\end{array}$ & $40-50$ \\
\hline $\begin{array}{l}\text { Hipodiploidia/ } \\
\text { /pseudodiploidia** }\end{array}$ & & $\begin{array}{c}\text { Często skojarzona } \\
\text { z aberracjami IGH/14q32 }\end{array}$ & $\begin{array}{l}\text { FISH } \\
\text { CC }\end{array}$ & $\sim 45$ \\
\hline
\end{tabular}

Najczęstsze powtarzalne translokacje $z$ udziałem genów immunoglobulinowych scharakteryzowano $\mathrm{w}$ tabeli 2 . Według jednej $z$ teorii bliska lokalizacja chromosomów 14, 11 i 4 podczas pewnych etapów SHM i CSR wyjaśnia preferencyjne powstawanie najczęstszych translokacji w PCM, to jest $\mathrm{t}(11 ; 14)$ i $\mathrm{t}(4 ; 14)$ [23]. Tak jak w innych nowotworach B-komórkowych aberracje te skutkują nasileniem ekspresji onkogenów poprzez zestawienie ich z silnymi wzmacniaczami kontrolującymi w prawidłowych warunkach ekspresję genów immunoglobulinowych. Prowadzi to do deregulacji wielu procesów w komórce, w tym niezwykle istotnego w cyklu komórkowym przejścia między fazami G1 i S [67, 68]. W MGUS i PCM można wyróżnić trzy podstawowe grupy powtarzających się translokacji obejmujących gen $I G H$ dotyczące trzech rodzajów onkogenów: genów cyklin $\mathrm{D}(\mathrm{t}(11 ; 14)$ — gen CCND1, t $(6 ; 14)$ - gen CCND3), genów czynników transkrypcyjnych $M A F(\mathrm{t}(14 ; 16)$ - gen $M A F, \mathrm{t}(14 ; 20)$ - gen $M A F B)$ oraz translokację $\mathrm{t}(4 ; 14)$ obejmującą geny $F G F R 3$ i $M M S E T$. $Z$ wyjątkiem FGFR3 żadna $z$ inicjujących translokacji nie dotyczy silnych onkogenów, co umożliwia atypowym plazmocytom przejście końcowych etapów różnicowania, a następnie osadzenie w niszach szpiku kostnego [69]. W obrębie pierwszej grupy obserwuje się translokacje genu cykliny D1 (CCND1, locus 11q13) u około 15\% chorych, cykliny D2 (CCND2, locus 12p13) - u mniej niz $1 \%$ pacjentów oraz cykliny D3 (CCND3, locus 6p25) - u $2 \%$ chorych [69]. Uważa się, że translokacje dotyczące genów cykliny D wyłącznie zwiększają ich ekspresję. Translokacje genów $M A F(16 \mathrm{q} 23-M A F-5 \%, 20 \mathrm{q} 12-M A F B-2 \%$, 8q24.3-MAFA < 1\%) nie tylko powodują zmiany w regulacji ekspresji czynników transkrypcyjnych MAF (v-maf avian musculoaponeurotic fibrosarcoma oncogene homolog), ale również przyczyniają się do wzrostu ekspresji wielu genów, w tym cykliny D2, a także cząsteczek adhezyjnych zwiększających zdolność interakcji komórek nowotworowych z mikrośrodowiskiem szpiku kostnego [70, 71]. Trzecią odmienną grupę stanowi translokacja t(4;14) obserwowana u 12-15\% chorych [72], która może obejmować jednocześnie aż dwa onkogeny - MMSET i FGFR3. Rola obu genów w patogenezie PCM jest niejasna, przy czym nadekspresję genu MMSET obserwuje się we wszystkich nowotworach $z$ translokacją $\mathrm{t}(4 ; 14)$, natomiast okolo $20 \%$ spośród tych chorych nie ma chromosomu pochodnego - der(14) i tym samym ekspresji genu FGFR3. Rzadkie występowanie mutacji aktywujących $F G F R 3$ w czasie progresji PCM potwierdza 
jednak potencjalną rolę tego genu w patogenezie PCM. Z kolei MMSET (multiple myeloma SET domain) jest metylotransferazą histonową dla histonu H3K36me2, a jej nadekspresja prowadzi do globalnego wzrostu metylacji H3K36me2 oraz znacznego zmniejszenia metylacji H3K27me3 [73-75]. Ostatnio stwierdzono również, że MMSET pełni ważną rolę w naprawie DNA. Po uszkodzeniu DNA dochodzi do fosforylacji MMSET (Ser102 oraz ATM), co w procesie kolejnych aktywacji innych genów prowadzi do akumulacji p53 i zatrzymania cyklu komórkowego w punkcie kontrolnym G2/M. W około połowie przypadków krytyczne punkty translokacji $\mathrm{t}(4 ; 14) \mathrm{w}$ PCM skutkują utratą Ser102 w MMSET, co powoduje zaburzenie prawidłowego szlaku odpowiedzi na uszkodzenie DNA [76].

Alternatywnym szlakiem patogenetycznym PCM jest występowanie charakterystycznych trisomii. Blisko połowa MGUS i PCM jest hiperdiploidalna, zawierając w komórkach 48-75 (najczęściej 49-56) chromosomów, zwykle $z$ obecnością dodatkowych kopii trzech lub większej liczby chromosomów nieparzystych, w tym chromosomów 3 , $5,7,9,11,15,19$ i 21 . W przypadkach $z$ hiperdiploidią, w początkowej fazie choroby, translokacje $z$ udziałem $I G H$ stwierdza się zaledwie u około $10 \%$ chorych [77], co świadczy o odrębności tych szlaków onkogenezy. Jednak zarówno mechanizmy powstawania trisomii, jak i molekularne konsekwencje prowadzące do rozwoju nowotworów plazmocytowych pozostają dotychczas nieznane. Wiadomo jednak, że u pacjentów $z$ hiperdiploidią przebieg PCM jest korzystniejszy, co może wynikać $z$ większej zależności od mikrośrodowiska szpiku kostnego.

Oprócz udziału w transformacji nowotworowej komórki plazmatycznej wzmożona ekspresja cyklin wydaje się odgrywać istotną rolę również w ewolucji nowotworu plazmocytowego do kolejnych stadiów. Już na etapie MGUS, mimo zerowego indeksu proliferacyjnego, stwierdza się podwyższone stężenie mRNA cykliny D1, D2 lub D3 w stosunku do zdrowych plazmocytów. Nadekspresja cyklin jest wynikiem różnych mechanizmów, w tym bezpośredniego, w translokacjach obejmujących geny cyklin $\mathrm{D}$, w tym $\mathrm{t}(11 ; 14), \mathrm{t}(6 ; 14)$ i t $(12 ; 14)$ [70]. Translokacja $t(14 ; 16)$ powoduje zwiększoną ekspresję cykliny D2, ponieważ ulegający translokacji onkogen $M A F$ koduje czynnik transkrypcyjny wiążący się bezpośrednio z promotorem genu CNCD2 [70]. Natomiast mechanizm wysokiego stężenia cykliny D2 u chorych z translokacją MMSET/FGFR3 pozostaje niewyjaśniony. Również większość PCM z hiperdiploidią charakteryzuje się wzmożoną ekspresją cykliny D1. Prawdopodobnie wynika to $z$ faktu, że w tego typu nowotworach dość często występuje trisomia chromosomu $11 \mathrm{z}$ locus dla genu CCND1 [70]. Tylko niewielki odsetek PCM nie wykazuje ekspresji żadnego $z$ genów cyklin D, jednak w tej grupie często stwierdza się delecję obu alleli genu $R B 1$, który jest inhibitorem cyklu komórkowego wiążącym się bezpośrednio z cykliną D [69].

Poza wyżej omówionymi pierwotnymi defektami onkogenezy u chorych na PCM obserwuje się bardzo wiele innych, wtórnych nieprawidłowości molekularnych, w tym aneuploidii, delecji, amplifikacji i mutacji genowych oraz zmian epigenetycznych, które poprzez modyfikację ekspresji licznych genów prowadzą do zaburzeń funkcji wielu szlaków metabolicznych. Szczególnie istotna w tym procesie wydaje się inhibicja genów supresorowych poprzez mutacje inaktywujące i delecje obu alleli lub zjawisko utraty heterozygotyczności ( $\mathrm{LOH}$, loss of heterozygosity). Do głównych supresorów uczestniczących w rozwoju i progresji PCM należą geny: FAM46C (family with sequence similarity 46, member C), DIS3, CYLD (cylindromatosis), BIRC2 (baculoviral IAP repeatcontaining protein 2), TRAF3 (tumour necrosis factor receptor-associated factor 3), TP53 i RB1 [78-83]. Gen $R B 1$, podobnie jak wspomniane wyżej protoonkogeny, uczestniczy w regulacji zmiany faz G1/S cyklu komórkowego, a jego inaktywacja w postaci utraty fragmentu chromosomu 13 jest obserwowana u 58\% chorych na PCM [79]. Trzy kolejne regiony $z$ genami supresorowymi, podlegające w $\mathrm{PCM}$ zjawisku $\mathrm{LOH}$, to $11 \mathrm{q}$ (BIRC2 i BIRC3), 16q (CYLD) i 14q32 (TRAF3) $[81,83,84]$. Wszystkie wymienione geny są zaangażowane w szlak czynnika transkrypcyjnego, jakim jest czynnik jądrowy $\kappa \mathrm{B}(\mathrm{NF} \kappa \mathrm{B}$, nuclear factor $\kappa B)$, co wskazuje, że jego konstytutywna aktywacja pełni istotną rolę w rozwoju PCM. Kolejnymi ważnymi $\mathrm{w}$ patogenezie PCM zmianami genetycznymi są amplifikacje określonych fragmentów DNA, które prowadzą do nadekspresji genów lub powstania mutacji aktywujących onkogeny. Klasycznym przykładem takiej aberracji jest duplikacja chromosomu 1q, który zawiera kilka istotnych onkogenów, w tym: CKS1B (CDC28 protein kinase $1 B)$, ANP32E (acidic leucine rich nuclear phosphoprotein 32 family, member E), BCL-9 i PDZK1 [79]. W badaniach wykazano także amplifikacje materiału genetycznego prowadzące do aktywacji szlaku czynnika transkrypcyjnego $\mathrm{NF} \kappa \mathrm{B}$, w tym amplifikację genu NIK (znany też jako MAPK3K14), TACI (określany inaczej TNFRSF13B) i LTBR (receptor $\beta$ limfotoksyny) [83]. 
Bardzo częste są również różne zaburzenia (translokacje, delecje, amplifikacje) obejmujące 8q24 - locus dla kluczowego w biologii PCM onkogenu $M Y C$ [85]. Wyniki ostatnich badań wykazały istotny związek nadekspresji genu $M Y C \mathrm{z}$ progresją stadiów prekursorowych do pełnoobjawowego PCM. Dowodem na to może być wyraźny wzrost częstości występowania aberracji w obrębie locus $8 \mathrm{q} 24$ wraz z postępem rozwoju PCM (MGUS $<1 \%$, PCM nowo zdiagnozowany - $15 \%$, zaawansowane stadia PCM > 50\%) [66].

Kolejnym istotnym aspektem patogenezy PCM są zmiany epigenetyczne, w tym głównie określone modyfikacje DNA i histonów wpływające na modulację ekspresji genów; DNA może podlegać modyfikacji poprzez metylację reszt cytozynowych $\mathrm{w}$ dinukleotydach $\mathrm{CpG}$. Ponadto do zmian struktur chromatyny dochodzi także w wyniku metylacji, fosforylacji, acetylacji oraz ubikwitynacji histonów [86]. Najważniejszymi zmianami epigenetycznymi obserwowanymi w przebiegu transformacji MGUS do PCM są uogólniona hipometylacja DNA oraz specyficzna genowo hipermetylacja DNA [87]. Poza wspomnianym wyżej onkogenem MMSET wśród modyfikatorów chromatyny związanych z zaburzeniami funkcji w PCM wymienia się między innymi demetylazę 6A (KDM6A, znana też jako UTX) i 6B (KDM6B), MLL (mixed-lineage leukemia) oraz HOXA9 (homeobox A9) [87, 88].

Analiza różnorodnych mutacji występujących w różnych zestawieniach i $z$ odmienną częstością u pacjentów z MGUS, SMM i PCM wskazuje, że $\mathrm{w}$ procesie rozwoju i progresji $\mathrm{PCM}$ znaczenie mają podobne efekty różnych anomalii genetycznych prowadzące do deregulacji określonych szlaków enzymatycznych w komórce nowotworowej. Przykładem może być stwierdzanie częstych mutacji $\mathrm{w}$ obrębie genów uczestniczących w regulacji szlaku ERK (anti-extracellular signal-regulated kinase) (gen NRAS u 24\% chorych, KRAS u 27\% i $B R A F$ u $4 \%$ ), co świadczy o istotnej roli tego szlaku w ekspansji nowotworowej atypowych plazmocytów [78]. Innym szlakiem enzymatycznym pełniącym ważną funkcję w rozwoju PCM jest szlak 3-kinazy fosfatydyloinozytolu (PI3K, phosphatidylinositol 3 kinase). Ufosforylowana kinaza AKT, która stanowi wskaźnik aktywności szlaku PI3K, jest wykrywana u 50\% chorych na PCM [89]. Ponadto w badaniach zaobserwowano, że pozytywny regulator szlaku PI3K - białko DEPTOR (DEP domain-containing mTOR-interacting protein) często wykazuje wzmożoną aktywność, szczególnie u tych chorych, u których stwierdza się także translokację genu MAF [90].
Uważa się, że w procesie inicjacji i progresji PCM kluczowe jest współdziałanie różnorodnych zmian genetycznych, a nie pojedyncze mutacje. Hipotezę tę potwierdzono w badaniach, w których wykazano, że choć $\mathrm{t}(14 ; 16)$ obejmująca gen $M A F$ wiąże się $z$ bardzo niekorzystnym rokowaniem u chorych na PCM, to u pacjentów $z$ MGUS takiej korelacji nie zaobserwowano [91, 92]. Wyniki te wskazują, że izolowane zaburzenie regulacji ekspresji genu $M A F$ nie wpływa bezpośrednio na rokowanie. $\mathrm{W}$ innych badaniach stwierdzono, że nagromadzenie niekorzystnych prognostycznie aberracji cytogenetycznych, takich jak $\mathrm{t}(4 ; 14)$, $\mathrm{t}(14 ; 16), \mathrm{t}(14 ; 20)$, del17p, amplifikacja 1q, wiąże się ze zdecydowanie gorszym rokowaniem niż występowanie tych zaburzeń osobno [91, 93, 94]. Z kolei stwierdzenie co najmniej jednej trisomii przyczynia się do mniej agresywnego przebiegu PCM w porównaniu $z$ karioptypem bez hiperdiploidii [95].

W ostatnio opublikowanych wynikach badań NGS obejmujących całe genomy lub eksomy wykazano, że średnia liczba stwierdzonych różnych mutacji pojedynczych nukleotydów u chorego na PCM wynosi 55-60, co pod względem złożoności sytuuje PCM między ostrymi białaczkami (kilka-kilkanaście mutacji) a guzami litymi (średnio kilkaset mutacji) [96]. Co istotne, u chorych na PCM nie stwierdzono jednak powtarzalnych mutacji, a wykrywane mutacje najczęściej były obecne tylko we frakcji komórek PCM [97]. Obserwacje te świadczą o tym, że są to zmiany wtórne w przebiegu progresji i ewolucji klonalnej PCM.

Poza zmianami genetycznymi $\mathrm{w}$ procesie transformacji MGUS do PCM niezwykle istotną rolę odgrywa także bezpośrednia i pośrednia (cytokinowa) stymulacja klonu nowotworowego przez komórki mikrośrodowiska szpiku kostnego, którą omówiono w części „Rola mikrośrodowiska szpiku kostnego w patogenezie PCM”. Główne, omówione wyżej, zjawiska odpowiedzialne za rozwój i progresję PCM przedstawiono na rycinie 2 .

\section{Molekularna heterogenność klonu nowotworowego}

W opracowanej w latach 70. ubiegłego wieku i obecnie dobrze udokumentowanej koncepcji heterogenności i ewolucji klonalnej nowotworu zakłada się występowanie losowych mutacji w obrębie pojedynczych komórek klonu nowotworowego, które są dziedziczone przez komórki potomne i powodują powstanie odmiennych populacji komórek nazywanych subklonami [98]. Przyczyną powstawania i w szczególności przetrwania nowych mutacji jest 


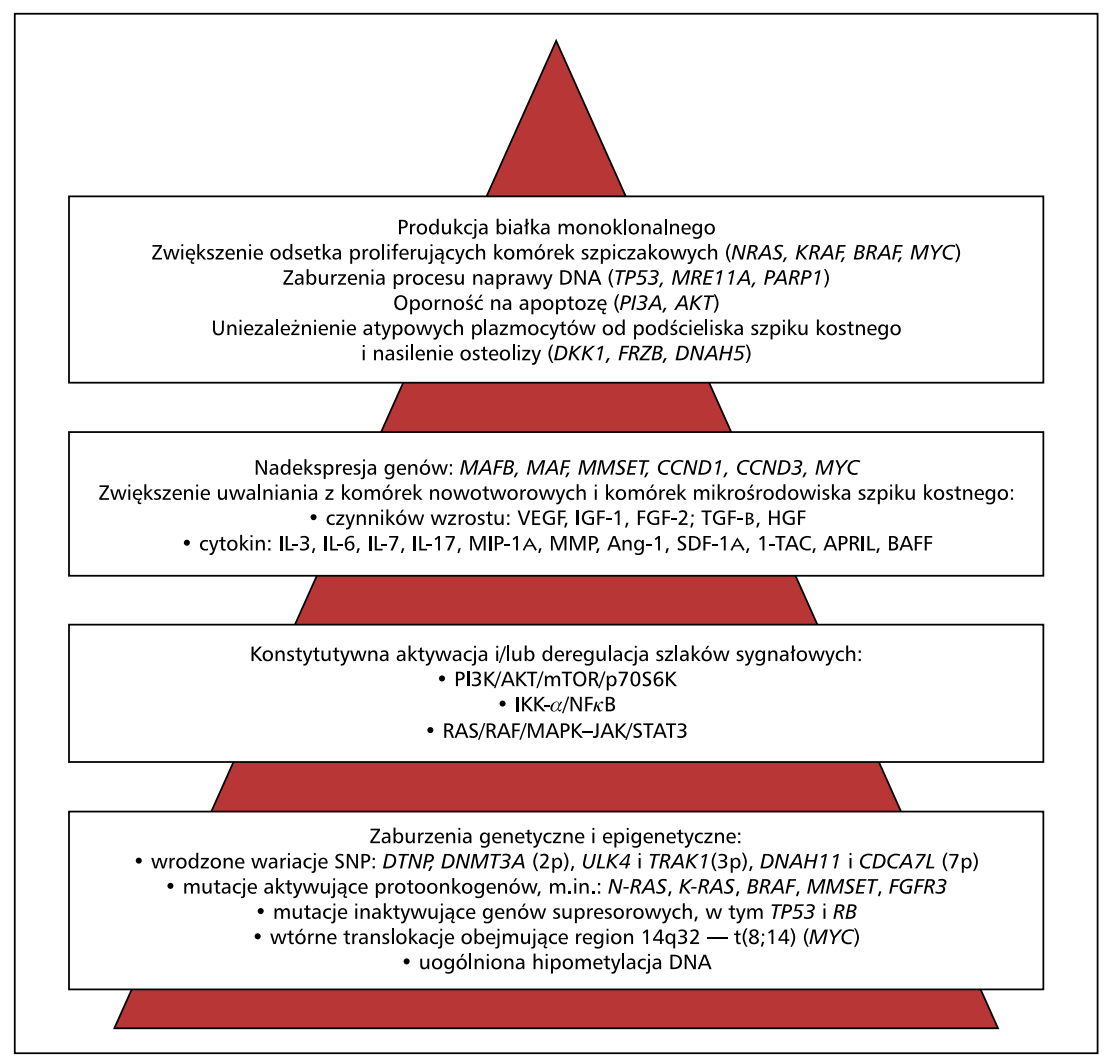

Rycina 2. Zaburzenia genetyczne i molekularne prowadzące do transformacji gammopatii monoklonalnej o nieokreśIonym znaczeniu do szpiczaka plazmocytowego; VEGF — czynnik wzrostu śródbłonka naczyniowego; IGF-1 — insulinopodobny czynnik wzrostu 1; FGF-2 - czynnik wzrostu fibroblastów 2; TGF $\beta$ - transformujący czynnik wzrostu $\beta$; HGF — czynnik wzrostu hepatocytów; IL — interleukina; MIP-1 $\alpha$ — białko zapalne makrofagów $1 \alpha$; MMP — metaloproteinaza macierzy zewnątrzkomórkowej; Ang-1 — angiopoetyna 1; SDF-1 — czynnik z komórek zrębowych 1 $\alpha$; 1-TAC — transforming acidic coiled coil; APRIL — ligand wywołujący proliferację; BAFF — czynnik aktywujący komórki B należący do rodziny TNF; PI3K - 3-kinaza fosfatydyloinozytolu; mTOR - ssaczy cel rapamycyny; IKK- $\alpha$ - kinaza $\alpha$ I $\kappa$; $\mathrm{NF} \kappa \mathrm{B}$ - czynnik jądrowy $\kappa \mathrm{B}$; MAPK - kinaza białkowa aktywowana mitogenem; JAK — kinaza Janus; STAT3 — transduktor sygnału i aktywator transkrypcji 3; SNP — polimorfizm pojedynczego nukleotydu

Figure 2. Genetic and molecular disorders leading to transformation of the monoclonal gammopathy of undetermined significance to the plasma cel myeloma; VEGF — vascular endothelial growth factor; IGF-1 — insulin-like growth factor 1; FGF-2 - fibroblast growth factor receptor 2; TGF $\beta$ - transforming growth factor $\beta$; HGF - hepatocyte growth factor; IL — interleukin; MIP- $1 \alpha$ - macrophage inflammatory protein $1 \alpha$; MMP - matrix metalloproteinase; Ang-1 - angiopoietin 1; SDF1 - stromal cell-derived factor 1; 1-TAC — transforming acidic coiled coil; APRIL — A proliferation-inducing ligand; BAFF — B-cell activating factor belonging to the TNF family; PI3K — phosphatidylinositol 3 kinase; mTOR - mammalian target of rapamycin kinase; IKK- $\alpha-\mathrm{l} \alpha \mathrm{B}$ kinase $\kappa$; NF $\kappa \mathrm{B}-$ nuclear factor $\kappa \mathrm{B}$; MAPK - mitogen-activated protein kinase; JAK — Janus kinase; STAT3 - signal transducer and activator of transcription 3; SNP — single nucleotide polymorphism

niestabilność genetyczna, która zwykle narasta $z$ czasem trwania nowotworu. Pod wpływem presji selekcyjnej różnych czynników genetycznych i środowiskowych, na przykład interakcji $z$ komórkami mikrośrodowiska lub chemioterapii, poszczególne subklony konkurują ze sobą i ulegają ekspansji lub redukcji. W ten sposób subklony mogą się wzajemnie wypierać i zastępować zależnie od potencjału proliferacyjnego i stopnia przystosowania do aktualnych warunków, podobnie jak w modelu ewolucji gatunków zaproponowanym przez Karola Darwina [99].

Za występowaniem heterogenności klonalnej w PCM przemawiały obserwacje kliniczne chorych, u których stwierdzano jednoczesne występowanie kilku prążków białka monoklonalnego, czasami o różnej restrykcji lańcuchów ciężkich lub lekkich (tzw. oligoklonalność), a także nawroty pod postacią tak zwanej ucieczki lekkiego łańcucha (utrata zdolności do wydzielania pełnych cząsteczek 
immunoglobulin). Jednak dopiero nowoczesne genomowe techniki molekularne, między innymi porównawcza hybrydyzacja genomowa (CGH, comparative genomic hybridization), a szczególnie głębokie sekwencjonowanie (NGS, next-generation sequencing), pozwoliły na poznanie złożonej architektury subklonalnej klonu nowotworowego PCM [100].

W jednej $z$ prac w NGS genów łańcuchów lekkich i ciężkich wykazano oligoklonalność u $12 \%$ spośród badanych 193 pacjentów z rozpoznaniem PCM [101]. W około 70\% spośród tych przypadków wykryte sekwencje były powiązane, co sugeruje późniejszą ewolucję ze wspólnego klonu pierwotnego. Pochodne klony powstały w wyniku zjawiska zmiany klas u 73\% i zjawiska SHM u $27 \%$ badanych chorych. Świadczy to, że te procesy moga zachodzić również po ostatecznym różnicowaniu komórki B do plazmocytu oraz po transformacji nowotworowej. Oprócz genów immunoglobulinowych $\mathrm{w}$ opisanych dotychczas analizach heterogenności wewnątrzklonalnej w PCM opisano mutacje wielu różnych genów [99, 101, 102]. Wstępne badania sekwencyjnych próbek, pobranych na różnych etapach choroby od tych samych pacjentów, wykazały pewne różnice między materiałem genetycznym $z$ okresu rozpoznania a DNA wyizolowanym $z$ próbek guza w okresie nawrotu [99, 103]. W części przypadków zmiany te były obecne we wszystkich komórkach, co odpowiadało klasycznej wizji ewolucji klonalnej $z$ nabywaniem kolejnych aberracji $\mathrm{w}$ przebiegu procesu nowotworowego. Jednak $\mathrm{u}$ innych chorych stwierdzono zmiany, które dotyczyły tylko części komórek (subklonalne), co więcej - stwierdzano również fragmenty DNA nieobecne w czasie rozpoznania PCM. Te obserwacje sugerują, że już w chwili rozpoznania PCM współistnieją różne subklony komórek nowotworowych, a więc heterogenność klonalna występuje prawdopodobnie już na bardzo wczesnym etapie onkogenezy [99, 102, 104]. Zaobserwowano również narastanie heterogenności wewnątrzklonalnej od stadium prekursorowego MGUS i SMM, poprzez objawy PCM, aż do najbardziej złożonej molekularnie białaczki plazmocytowej [105]. Co niezwykle istotne, choć niektóre populacje subklonalne mogą być wyjściowo bardzo nieliczne i niemożliwe do detekcji stosowanymi obecnie metodami, to mogą stanowić źródło nawrotu. Ostatnio w bardzo interesującym badaniu scharakteryzowano cztery podstawowe wzory ewolucji klonalnej obserwowanej w PCM [96].

Nie ulega wątpliwości, że istotnym czynnikiem selekcji poszczególnych subklonów jest ich odmienna wrażliwość na stosowany rodzaj chemioterapii. Zostało to bardzo wyraźnie udowodnione w kilku ostatnich badaniach, w których analizowano sekwencyjne próbki od tych samych pacjentów $z$ kolejnych nawrotów [102]. Jednak ważną rolę odgrywają zapewne też inne czynniki, na przykład interakcje PCM z mikrośrodowiskiem szpiku. Należy również zauważyć, że teoretycznie suboptymalne leczenie może doprowadzić do ekspansji bardziej agresywnego, opornego subklonu kosztem subklonu łagodnego, ale wrażliwego na określony lek. $Z$ tego względu wiedza o heterogenności klonalnej PCM jest silnym argumentem przemawiającym za stosowaniem złożonego i długotrwałego leczenia, które atakowałoby największą liczbę subklonów.

\section{Rola mikrośrodowiska szpiku kostnego w patogenezie $\mathrm{PCM}$}

Powszechnie uważa się, że obok zmian molekularnych w obrębie klonu plazmocytowego kluczową rolę w patogenezie PCM odgrywa mikrośrodowisko szpiku kostnego. Termin „mikrośrodowisko (podścielisko) szpiku” obejmuje macierz zewnątrzkomórkową zbudowaną głównie $z$ włókien kolagenowych oraz wiele typów komórek, w tym mezenchymalnych komórek macierzystych (MSC, mesenchymal stromal cells), komórek zrębu szpiku kostnego (BMSC, bone marrow stromal cells), fibroblastów, osteoklastów, osteoblastów, limfocytów T, komórek dendrytycznych i komórek śródbłonka naczyniowego. Fizjologiczną rolą podścieliska szpiku kostnego jest regulacja oraz podtrzymywanie wzrostu i różnicowania komórek krwiotwórczych. W patogenezie PCM wzajemne interakcje między komórkami mikrośrodowiska (w szczególności komórkami śródbłonka i MSC) oraz klonem nowotworowym zachodzą na zasadzie bezpośrednich oddziaływań powierzchniowych cząsteczek adhezyjnych i receptorowych, a także za pośrednictwem uwalnianych przez te komórki parakrynnych mediatorów umożliwiających przeżycie, proliferację i różnicowanie atypowych plazmocytów [106-109]. Udział mikrośrodowiska szpiku kostnego jest istotny na każdym etapie ewolucji klonu plazmocytowego i dotyczy wielu zróżnicowanych procesów w patogenezie PCM, $\mathrm{w}$ tym zasiedlania szpiku kostnego, inwazji do nowych regionów szpiku i lokalizacji pozaszpikowych, osteoklastogenezy i hamowania osteogenezy oraz występowania wtórnych niedoborów odporności humoralnej i komórkowej [106].

Cząsteczkami adhezyjnymi uczestniczącymi w oddziaływaniach międzykomórkowych w procesie rozwoju PCM są przede wszystkim cząsteczka adhezji komórkowej naczyń 1 (VCAM-1, vascular 
cell adhesion molekule 1) i cząsteczka adhezji międzykomórkowej 1 (ICAM-1, intercellular adhesion molekule 1) ulegające ekspresji na powierzchni komórek BMSC oraz antygeny obecne na powierzchni plazmocytów, w tym antygen związany $z$ czynnością leukocytów (LFA-1, leukocyte function-associated antygen 1), integryna $\alpha \mathrm{V} \beta_{3}$, antygen bardzo późnej aktywacji 4 (VLA-4, very late activating antygen 4) oraz mucyna 1 (MUC-1). Skutkiem powyższych interakcji jest modyfikacja szlaków sygnałowych komórek prowadząca do wzmożonej ekspresji genów i tym samym nasilonej produkcji oraz wydzielania przez komórki nowotworowe czynników wzrostu (czynnika wzrostu hepatocytów (HGF, hepatocyte growth factor), czynnika martwicy nowotworów $\alpha$ (TNF $\alpha$, tumor necrosis factor $\alpha$ ), czynnika wzrostu fibroblastów 2 (FGF-2, fibroblast growth factor 2), czynnika wzrostu śródbłonka naczyniowego (VEGF, vascular endothelial growth factor), insulinopodobnego czynnika wzrostu 1 (IGF-1, insulin-like growth factor 1), transformującego czynnika wzrostu $\beta$ (TGF $\beta$, transforming growth factor $\beta$ ) $[110,111]$ oraz cytokin (m.in. IL-6, CXCL12/czynnika $z$ komórek zrębowych $1 \alpha$ [SDF- $1 \alpha$, stromal cell derived factor], angiopoetyny 1 [Ang-1]), które regulują przeżycie komórek nowotworowych oraz promują progresję PCM [112-114].

Neoangiogeneza, będąca jednym $z$ kluczowych procesów związanych $z$ rozwojem PCM, to także skutek interakcji zachodzących między atypowymi plazmocytami a komórkami podścieliska szpiku kostnego. Główną rolę pełnią w tym przypadku komórki śródbłonka, które w środowisku komórek szpiczakowych wykazują wzmożoną ekspresję czynników angiogennych, oraz ich receptorów, w tym VEGF i jego receptora 2 (VEGFR-2), FGF-2 i jego receptora 2 (FGF-2R-2), Ang-2 i śródbłonkowy receptor 2 dla kinazy tyrozynowej (Tie-2, endothelial tyrosine kinase receptor 2), a także konstytutywnych kinaz tyrozynowych - receptora $\beta$ płytkopochodnego czynnika wzrostu (PDGFR $\beta$, platelet-derived growth factor receptor $\beta$ ) i pp60-Src, co bezpośrednio wpływa na nasilenie tworzenia nowych naczyń krwionośnych [115-117]. W badaniach wykazano, że VEGF selektywnie indukuje szlak sygnałowy kinaz PDGF-BB/PDGFR $\beta$, który odpowiada za aktywację ERK1-2, AKT, a także nasilenie transkrypcji genów oraz wydzielanie z komórek śródbłonka IL-8 i VEGF. Efektorem pętli sygnalizacyjnej VEGF jest $z$ kolei kinaza pp60c-Src. Poza komórkami śródbłonka w procesie neowaskularyzacji w PCM uczestniczą również makrofagi, mastocyty, fibroblasty szpiku kostnego, a także osteoblasty i osteolasty.
W badaniach zaobserwowano, że makrofagi szpiku kostnego pochodzące od chorych na PCM, pod wpływem VEGF i FGF-2, mogą ulegać transformacji do komórek przypominających połączone komórki śródbłonka. Tak przeobrażone makrofagi tworzą sieć typu włośniczkowego, która zachodzi na sieć naczyń utworzoną z komórek śródbłonka $[118,119]$. Co ciekawe, zarówno typowe makrofagi, jak i te po transformacji w znacznym stopniu przyczyniają się do neoangiogenezy w PCM, co potwierdzono dzięki analizie budowy ścian mikronaczyń uzyskanych $z$ bioptatów szpiku kostnego chorych na PCM [119].

$Z$ kolei, analizując rolę mastocytów w rozwoju PCM, zaobserwowano, że w aktywnym PCM istnieje wyraźna dodatnia korelacja między liczbą tych komórek a aktywnością waskulogenezy w szpiku kostnym. Podobną zależność wykazano także w nieaktywnej postaci PCM oraz w MGUS, ale oba parametry cechowało mniejsze nasilenie niż w aktywnym PCM [118]. Kolejnym elementem podścieliska szpiku kostnego istotnym w patogenezie PCM są fibroblasty. Komórki te, poprzez wydzielanie cytokin i czynników wzrostu, wpływają nie tylko na tworzenie nowych naczyń, ale także zwiększają aktywność proliferacyjną komórek nowotworowych oraz ich zdolność do rozprzestrzeniania się, co przyczynia się do progresji PCM $\mathrm{w}$ postaci przyspieszonego wzrostu nowotworu oraz tworzenia się przerzutów [120]. Aktywne fibroblasty u chorych ze PCM wykazują zdolność do promowania procesów chemotaksji, adhezji, proliferacji, a także indukują oporność komórek nowotworowych na apoptozę. Oddziaływanie tych komórek $z$ atypowymi plazmocytami zachodzi zarówno poprzez wydzielane cytokiny, jak i bezpośredni kontakt międzykomórkowy. W badaniach zaobserwowano wyraźnie większy odsetek pobudzonych fibroblastów w szpiku kostnym chorych $z$ aktywnym PCM względem pacjentów $z$ MGUS lub w remisji choroby. Wykazano także, że komórki te charakteryzowała zdolność do wzmożonej produkcji i wydzielania cytokin i czynników wzrostu, przede wszystkim IL- 6 , TGF $\beta$, SDF- $1 \alpha$ i IGF-1, co wyraźnie wskazuje na istotną rolę fibroblastów $\mathrm{w}$ patogenezie PCM [121].

W procesie tworzenia nowych naczyń biorą także udział osteoblasty i osteoklasty. Komórki kościotwórcze wykazują ekspresję Ang-1. Z kolei komórki kościogubne wydzielają metaloproteinazę macierzy zewnątrzkomórkowej 9 (MMP-9, matrix metalloproteinase 9), która wspomaga neoangiogenezę poprzez uwalnianie $z$ macierzy zewnątrzkomórkowej czynnika VEGF [122]. Ponadto zarówno osteoblasty, jak 
i osteoklasty syntetyzują proangiogenną osteopontynę (OPN), która w procesie tworzenia sieci naczyń działa synergistycznie z VEGF [123]. Dodatkowo $\mathrm{w}$ badaniach dowiedziono, że hamowanie aktywności osteoklastów u chorych na PCM spowalnia proces angiogenezy [124].

Kolejnym mechanizmem związanym $z$ rozwojem i progresją PCM jest zjawisko aktywacji osteoklastów oraz inhibicji funkcji osteoblastów przez atypowe plazmocyty prowadzące do nasilonej osteolizy. Procesy te są związane $z$ wydzielaniem przez komórki nowotworowe oraz pod ich wpływem, przez komórki mikrośrodowiska szpiku kostnego, cytokin zwiększających ekspresję ligandu dla receptora aktywującego czynnik transkrypcyjny $\mathrm{NF}-\kappa \mathrm{B}$ (RANKL, receptor activator of nuclear factor $\kappa B$ ligand), do których przede wszystkim należą białko zapalne makrofagów $1 \alpha$ (MIP- $1 \alpha$, macrophage inflammatory protein $1 \alpha$ ), IL-3 oraz IL-6. Dodatkowo osteolizę w PCM wspomaga zwiększone wydzielanie przez atypowe plazmocyty oraz komórki stromalne szpiku kostnego cytokiny SDF-1 $\alpha$, która aktywuje osteoklasty poprzez związanie na prekursorach tych komórek receptora CXCR4. $Z$ kolei supresyjne oddziaływanie na osteoblasty odbywa się głównie poprzez znaczne zmniejszenie ekspresji naturalnego inhibitora RANKL — osteoprotegryny, $z$ jednoczesnym $z$ większeniem inaktywatora tego białka, którym jest syndekan 1 (CD138). Ponadto działania kościotwórcze są blokowane przez wzrost stężenia IL-3 i IL-7 oraz białka Dickkopf (DKK1), będącego składową kanonicznego szlaku Wnt, kluczowego w indukcji różnicowania i proliferacji osteoblastów [125, 126].

Analizując rolę komórek mikrośrodowiska w rozwoju i progresji PCM warto zauważyć, że część zaobserwowanych interakcji wydaje się odpowiadać procesom zachodzącym również w stosunku do prawidłowych plazmocytów rezydujących w szpiku kostnym, natomiast pozostałe są wynikiem zaburzonej kompozycji podścieliska szpiku kostnego w odpowiedzi na klon PCM. Wspomniane wyżej interakcje zapewne odgrywają rolę w zasiedlaniu przez nowotworowe plazmocyty specjalnych nisz szpiku kostnego, co prawdopodobnie stanowi jeden $z$ mechanizmów zwiększający ich zdolność do przeżycia [127, 128]. W warunkach fizjologicznych w niszach tych osiadają prawidłowe komórki plazmatyczne i jako długożyjące plazmocyty mogą przetrwać wiele lat, stanowiąc element pamięci immunologicznej. Mechanizmy, dzięki którym komórki PCM uzyskują przewagę w zasiedlaniu nisz nad prawidłowymi plazmocytami, nie zostały jeszcze wyjaśnione.

\section{Konsekwencje kliniczne wiedzy o etiopatogenezie PCM}

Liczne w ostatnich latach wyniki badań świadczące o bardzo znacznym zróżnicowaniu PCM pod względem molekularnym przemawiają jednoznacznie za indywidualizowanym podejściem terapeutycznym, mimo podobnego morfologicznie i klinicznie obrazu rozrostu komórek plazmocytowych. Obecnie podstawą kwalifikacji pacjenta do określonej grupy ryzyka jest przede wszystkim panel zaburzeń cytogenetycznych wykrywanych metodą FISH oraz stadium zaawansowania według międzynarodowego indeksu prognostycznego. Jednak trwają próby udoskonalenia oceny rokowania, między innymi poprzez stosowanie w tym celu różnych zestawów do profilowania ekspresji genów (GEP, gene expression profiling), a także NGS.

Dalszy postęp wiedzy na temat zaburzeń molekularnych występujących u chorych na PCM powinien się przyczynić do opracowania bardziej precyzyjnych wskaźników prognostycznych oraz umożliwić dobór najwłaściwszej terapii w określonych grupach pacjentów. Jednak już dotychczasowa wiedza pozwala na pewien stopień indywidualizacji leczenia. Przykładem takiej strategii jest terapia bortezomibem chorych z $\mathrm{t}(4 ; 14)$, która wyraźnie wpłynęła na poprawę rokowania w tej populacji pacjentów [11, 129-131]. Ponadto wiadomo, że stosowanie leków immunomodulujących jest bardziej korzystne dla chorych $z$ grupy niskiego ryzyka, ale leczenie podtrzymujące talidomidem $\mathrm{u}$ chorych obciążonych wysokim ryzykiem cytogenetycznym może nawet pogarszać rokowanie [132, 133]. Jednocześnie warto zauważyć, że część chorych $z$ grupy wysokiego ryzyka osiagga długi czas przeżycia w przypadku zastosowania standardowych schematów terapeutycznych. Świadczy to o zbyt małej swoistości poznanych zaburzeń molekularnych i niedoskonałości obecnych systemów rokowniczych [132, 134-136].

Coraz szerzej stosuje się również badania metodą NGS umożliwiające przede wszystkim identyfikację mutacji somatycznych, co może ułatwić stworzenie terapii celowanej. Jednak w odniesieniu do potencjalnej skuteczności nowych celowanych leków niekorzystnym zjawiskiem wydaje się, omówiona wyżej, heterogenność wewnątrzklonalna PCM. Wybiórcze działanie leku wobec komórek $z$ określonym zaburzeniem molekularnymi może powodować tylko przejściowy efekt kliniczny ze względu na selekcję innych, bardziej opornych i agresywnych klonów. Przykładem takiego zjawiska są wyniki próby leczenia chorych $\mathrm{z}$ mutacją 
V600E genu kinazy serynowo-treoninowej BRAF wemurafenibem, który powodował spektakularne, ale krótkotrwałe remisje [137]. Teoretycznie do podobnej sytuacji może doprowadzić wczesne, mało intensywne, leczenie chorych na SMM. Taka terapia mogłaby w wybranych sytuacjach spowodować zniszczenie indolentnego klonu plazmocytów i utorować drogę do szybkiego rozwoju innego, opornego na zastosowane leczenie subklonu komórek nowotworowych. Zatem nowe dane o heterogenności wewnątrzklonalnej PCM są dodatkowym argumentem na rzecz złożonego, wielokierunkowego i długotrwałego leczenia chorych na PCM.

\section{Podsumowanie}

W podsumowaniu należy stwierdzić, że dalszy dynamiczny rozwój wiedzy o mechanizmach patogenetycznych PCM umożliwi opracowanie lepszych systemów prognostycznych, a także celowanych i dobieranych indywidualnie strategii terapeutycznych, co może prowadzić do dalszej poprawy wyników leczenia, a nawet wyleczenia części chorych.

\section{Piśmiennictwo}

1. Landgren O., Kyle R.A., Pfeiffer R.M. i wsp. Monoclonal gammopathy of undetermined significance (MGUS) consistently precedes multiple myeloma: a prospective study. Blood 2009; 113: 5412-5417.

2. Weiss B.M., Abadie J., Verma P., Howard R.S., Kuehl W.M. A monoclonal gammopathy precedes multiple myeloma in most patients. Blood 2009; 113: 5418-5422.

3. Dispenzieri A., Katzmann J.A., Kyle R.A. i wsp. Prevalence and risk of progression of light-chain monoclonal gammopathy of undetermined significance: a retrospective population-based cohort study. Lancet 2010; 375: 1721-1728.

4. Kyle R.A., Therneau T.M., Rajkumar S.V. i wsp. Prevalence of monoclonal gammopathy of undetermined significance. N. Engl. J. Med. 2006; 354: 1362-1369.

5. Walker B.A., Wardell C.P., Lopez-Corral L. i wsp. Whole genome sequencing illuminates the genetic and biological features underlying the transition of SMM to MM. Blood 2011; 118: abstrakt 296.

6. Flactif M., Zandecki M., Laï J.L. i wsp. Interphase fluorescence in situ hybridization (FISH) as a powerful tool for the detection of aneuploidy in multiple myeloma. Leukemia 1995; 9: 2109-2114.

7. Ladetto M., Brüggemann M., Monitillo L. i wsp. Next-generation sequencing and real-time quantitative PCR for minimal residual disease detection in B-cell disorders. Leukemia 2014; 28: 1299$-1307$.

8. Lionetti M., Agnelli L., Mosca L. i wsp. Integrative high-resolution microarray analysis of human myeloma cell lines reveals deregulated miRNA expression associated with allelic imbalances and gene expression profiles. Genes Chromosomes Cancer 2009; 48: 521-531.

9. Mateos M.V., Richardson P.G., Schlag R. i wsp. Bortezomib plus melphalan and prednisone compared with melphalan and predni- sone in previously untreated multiple myeloma: updated follow-up and impact of subsequent therapy in the phase III VISTA trial. J. Clin. Oncol. 2010; 28: 2259-2266.

10. Kumar S., Flinn I., Richardson P.G. i wsp. Randomized, multicenter, phase 2 study (EVOLUTION) of combinations of bortezomib, dexamethasone, cyclophosphamide, and lenalidomide in previously untreated multiple myeloma. Blood 2012; 119: 4375-4382.

11. Sonneveld P., Schmidt-Wolf I.G., van der Holt B. i wsp. Bortezomib induction and maintenance treatment in patients with newly diagnosed multiple myeloma: results of the randomized phase III HOVON-65/ GMMG-HD4 trial. J. Clin. Oncol. 2012; 30: 2946-2955.

12. Rosiñol L., Oriol A., Teruel A.-I. i wsp. Superiority of bortezomib, thalidomide, and dexamethasone (VTD) as induction pretransplantation therapy in multiple myeloma: a randomized phase 3 PETHEMA/GEM study. Blood 2012; 120: 1589-1596.

13. Miguel J.S., Weisel K., Moreau P. i wsp. Pomalidomide plus low-dose dexamethasone versus high-dose dexamethasone alone for patients with relapsed and refractory multiple myeloma (MM-003): a randomised, open-label, phase 3 trial. Lancet Oncol. 2013; 14: 1055-1066.

14. Jakubowiak A.J., Siegel D.S., Martin T. i wsp. Treatment outcomes in patients with relapsed and refractory multiple myeloma and high-risk cytogenetics receiving single-agent carfilzomib in the PX-171-003-A1 study. Leukemia 2013; 27: 2351-2356.

15. Nijhof I.S., Groen R.W., Noort W.A. i wsp. Preclinical evidence for the therapeutic potential of CD38-targeted immuno-chemotherapy in multiple myeloma patients refractory to lenalidomide and bortezomib. Clin. Cancer Res. 2015; 21: 2802-2810.

16. Broderick P., Chubb D., Johnson D.C. i wsp. Common variation at 3 p22.1 and 7p15.3 influences multiple myeloma risk. Nat. Genet. 2011; 44: 58-61.

17. Chubb D., Weinhold N., Broderick P. i wsp. Common variation at 3q26.2, 6p21.33, 17p11.2 and 22q13.1 influences multiple myeloma risk. Nat. Genet. 2013; 45: 1221-1225.

18. McShane C.M., Murray L.J., Landgren O. i wsp. Prior autoimmune disease and risk of monoclonal gammopathy of undetermined significance and multiple myeloma: a systematic review. Cancer Epidemiol. Biomarkers Prev. 2014; 23: 332-342.

19. Wang S.S., Voutsinas J., Chang E.T. i wsp. Anthropometric, behavioral, and female reproductive factors and risk of multiple myeloma: a pooled analysis. Cancer Causes Control 2013; 24: 1279-1289.

20. Grulich A.E., van Leeuwen M.T., Falster M.O., Vajdic C.M. Incidence of cancers in people with HIV/AIDS compared with immunosuppressed transplant recipients: a meta-analysis. Lancet 2007; 370: 59-67.

21. Lindqvist E.K., Goldin L.R., Landgren O. i wsp. Personal and family history of immune-related conditions increase the risk of plasma cell disorders: a population-based study. Blood 2011; 118: 6284-6291.

22. Malpas J.S., Bergsagel D.E., Kyle R., Anderson K. Multiple myeloma: biology and management. Oxford University Press, Oxford 2004.

23. Corre J., Munshi N., Avet-Loiseau H. Genetics of multiple myeloma: another heterogeneity level? Blood 2015; 125: 1870-1876.

24. Kuehl W.M., Bergsagel P.L. Multiple myeloma: evolving genetic events and host interactions. Nat. Rev. Cancer 2002; 2: 175-187.

25. Kuehl W.M., Bergsagel P.L. Early genetic events provide the basis for a clinical classification of multiple myeloma. Hematology Am. Soc. Hematol. Educ. Program 2005: 346-352. 
26. Walker B.A., Wardell C.P., Johnson D.C. Characterization of IGH locus breakpoints in multiple myeloma indicates a subset of translocations appear to occur in pregerminal center B cells. Blood 2013; 121: 3413-3419.

27. Tembhare P.R., Yuan C.M., Venzon D. i wsp. Flow cytometric differentiation of abnormal and normal plasma cells in the bone marrow in patients with multiple myeloma and its precursor diseases. Leuk. Res. 2014; 38: 371-376.

28. Hosen N. Multiple myeloma-initiating cells. Int. J. Hematol. 2013; 97: 306-312.

29. Al-Hajj M., Wicha M.S., Benito-Hernandez A., Morrison S.J., Clarke M.F. Prospective identification of tumorigenic breast cancer cells. Proc. Natl. Acad. Sci. USA 2003; 100: 3983-3988.

30. Singh S.K., Hawkins C., Clarke I.D. i wsp. Identification of human brain tumour initiating cells. Nature 2004; 432: 396-401.

31. O'Brien C.A., Pollett A., Gallinger S., Dick J.E. A human colon cancer cell capable of initiating tumour growth in immunodeficient mice. Nature 2007; 445: 106-110.

32. Matsui W., Wang Q., Barber J.P. i wsp. Clonogenic multiple myeloma progenitors, stem cell properties, and drug resistance. Cancer Res. 2008; 68: 190-197.

33. Hosen N., Matsuoka Y., Kishida S. i wsp. CD138-negative clonogenic cells are plasma cells but not B cells in some multiple myeloma patients. Leukemia 2012; 26: 2135-2141.

34. Bladé J., Kyle R.A., Greipp P.R. Presenting features and prognosis in 72 patients with multiple myeloma who were younger than 40 years. Br. J. Haematol. 1996; 93: 345-351.

35. Parkin D.M., Whelan S.L., Ferlay J., Teppo L., Thomas D.B. Cancer incidence in five continents. Vol. 8. IARC, Lyon 2002.

36. Waxman A.J., Mink P.J., Devesa S.S. i wsp. Racial disparities in incidence and outcome in multiple myeloma: a population-based study. Blood 2010; 116: 5501-5506.

37. Kristinsson S.Y., Björkholm M., Goldin L.R. i wsp. Patterns of hematologic malignancies and solid tumors among 37,838 first-degree relatives of 13,896 patients with multiple myeloma in Sweden. Int. J. Cancer 2009; 125: 2147-2150.

38. Lynch H.T., Sanger W.G., Pirruccello S., Quinn-Laquer B., Weisenburger D.D. Familial multiple myeloma: a family study and review of the literature. J. Natl. Cancer Inst. 2001; 93: 1479_ -1483 .

39. Ziakas P.D., Karsaliakos P., Prodromou M.L., Mylonakis E. Interleukin-6 polymorphisms and hematologic malignancy: a re-appraisal of evidence from genetic association studies. Biomarkers 2013; 18: 625-631.

40. Vangsted A.J., Nielsen K.R., Klausen T.W. i wsp. A functional polymorphism in the promoter region of the IL1B gene is associated with risk of multiple myeloma. Br. J. Haematol. 2012; 158: 515-518.

41. Du J., Yuan Z., Zhang C. i wsp. Role of the TNF- $\alpha$ promoter polymorphisms for development of multiple myeloma and clinical outcome in thalidomide plus dexamethasone. Leuk. Res. 2010; 34: 1453-1458.

42. Brito A.B., Lourenço G.J., Oliveira G.B. i wsp. Associations of VEGF and VEGFR2 polymorphisms with increased risk and aggressiveness of multiple myeloma. Ann. Hematol. 2014; 93: 1363-1369.

43. Birmann B.M., Tamimi R.M., Giovannucci E. i wsp. Insulin-like growth factor-1- and interleukin-6-related gene variation and risk of multiple myeloma. Cancer Epidemiol. Biomarkers Prev. 2009; 18: 282-288.

44. Thyagarajan B., Arora M., Guan W. i wsp. Genetic variants in DNA repair pathways are not associated with disease progres- sion among multiple myeloma patients. Leuk. Res. 2013; 37: 1527-1531.

45. Martino A., Sainz J., Manuel Reis R. Polymorphisms in regulators of xenobiotic transport and metabolism genes PXR and CAR do not affect multiple myeloma risk: a case-control study in the context of the IMMEnSE consortium. J. Hum. Genet. 2013; 58: 155-159.

46. Brown L.M., Gridley G., Check D., Landgren O. Risk of multiple myeloma and monoclonal gammopathy of undetermined significance among white and black male United States veterans with prior autoimmune, infectious, inflammatory, and allergic disorders. Blood 2008; 111: 3388-3394.

47. Ferlin M., Noraz N., Hertogh C. i wsp. Insulin-like growth factor induces the survival and proliferation of myeloma cells through an interleukin-6-independent transduction pathway. Br. J. Haematol. 2000; 111: 626-634.

48. Patel A.V., Diver W.R., Teras L.R., Birmann B.M., Gapstur S.M. Body mass index, height and risk of lymphoid neoplasms in a large United States cohort. Leuk. Lymphoma. 2013; 54: 1221-1227.

49. Koutros S., Baris D., Bell E. i wsp. Use of hair colouring products and risk of multiple myeloma among US women. Occup. Environ. Med. 2009; 66: 68-70.

50. Correa A., Jackson L., Mohan A., Perry H., Helzlsouer K. Use of hair dyes, hematopoietic neoplasms, and lymphomas: a literature review. II. Lymphomas and multiple myeloma. Cancer Invest. 2000; 18: 467-479.

51. Pahwa M., Beane Freeman L., Spinelli J.J. 0409 The North American Pooled Project (NAPP): Pooled analyses of case-control studies of pesticides and agricultural exposures, lymphohematopoietic cancers and sarcoma. Occup. Environ. Med. 2014; 71: A116.

52. Alavanja M.C., Hofmann J.N., Lynch C.F. i wsp. Non-hodgkin lymphoma risk and insecticide, fungicide and fumigant use in the agricultural health study. PLoS One 2014; 9: e109332.

53. Andreotti G., Birmann B.M., Cozen W. i wsp. A pooled analysis of cigarette smoking and risk of multiple myeloma from the international multiple myeloma consortium. Cancer Epidemiol. Biomarkers Prev. 2015; 24: 631-634.

54. Rota M., Porta L., Pelucchi C. i wsp. Alcohol drinking and multiple myeloma risk - a systematic review and meta-analysis of the dose-risk relationship. Eur. J. Cancer Prev. 2014; 23: 113-121.

55. Rajkumar V., Dimopoulos M.A., Palumbo A. International Myeloma Working Group updated criteria for the diagnosis of multiple myeloma. Lancet Oncol. 2014; 15: e538-e548.

56. Kyle R.A., Remstein E.D., Therneau T.M. i wsp. Clinical course and prognosis of smoldering (asymptomatic) multiple myeloma. N. Engl. J. Med. 2007; 356: 2582-2590.

57. Calasanz M.J., Cigudosa J.C., Odero M.D. i wsp. Cytogenetic analysis of 280 patients with muliple myeloma and related disorders: primary breakpoints and clinical correlations. Genes Chromosom Cancer 1997; 18: 84-93.

58. Nishida K., Tamura A., Nakazawa N. i wsp. The Ig heavy chain is frequently involved in chromosomal translocations in multiple myeloma and plasma cell leukemia as detected by in situ hybridization. Blood 1997; 90: 526-534.

59. Rajkumar S.V., Dispenzieri A., Kyle R.A. Monoclonal gammopathy of undetermined signifi cance, Waldenström macroglobulinemia, AL amyloidosis, and related plasma cell disorders: diagnosis and treatment. Mayo Clin. Proc. 2006; 81: 693-703.

60. Landgren O. Monoclonal gammopathy of undetermined significance and smoldering multiple myeloma: biological insights and 
early treatment strategies. Hematology Am. Soc. Hematol. Educ. Program 2013: 478-487.

61. Dewald G.W., Kyle R.A., Hicks G.A., Greipp P.R. The clinical significance of cytogenetic studies in 100 patients with multiple myeloma, plasma cell leukemia, or amyloidosis. Blood 1985; 66: 380-390.

62. Smadja N.V., Bastard C., Brigaudeau C., Leroux D., Fruchart C. Hypodiploidy is a major prognostic factor in multiple myeloma. Blood 2001; 98: 2229-2238.

63. Bergsagel P.L., Kuehl W.M. Chromosome translocations in multiple myeloma. Oncogene 2001; 20: 5611-5622.

64. Fonseca R., Bergsagel P.L., Drach J. i wsp. International myeloma working group molecular classification of multiple myeloma: spotlight review. Leukemia 2009; 23: 2210-2221.

65. Avet-Loiseau H., Facon T., Daviet A. i wsp. 14q32 translocations and monosomy 13 observed in monoclonal gammopathy of undetermined significance delineate a multistep process for the oncogenesis of multiple myeloma. Intergroupe Francophone du Myelome. Cancer Res. 1999; 59: 4546-4550.

66. Gabrea A., Martelli M.L., Qi Y. i wsp. Secondary genomic rearrangements involving immunoglobulin or MYC loci show similar prevalences in hyperdiploid and nonhyperdiploid myeloma tumors. Genes Chromosom Cancer 2008; 47: 573-590.

67. Gonzalez D., van der Burg M., García-Sanz R. i wsp. Immunoglobulin gene rearrangements and the pathogenesis of multiple myeloma. Blood 2007; 110: 3112-3121.

68. Reimold A.M., Iwakoshi N.N., Manis J. i wsp. Plasma cell differentiation requires the transcription factor XBP-1. Nature 2001; 412: 300-307.

69. Chesi M., Bergsagel P.L. Molecular pathogenesis of multiple myeloma: basic and clinical updates. Int. J. Hematol. 2013; 97: 313-323.

70. Bergsagel P.L., Kuehl W.M., Zhan F. i wsp. Cyclin D dysregulation: an early and unifying pathogenic event in multiple myeloma. Blood 2005; 106: 296-303.

71. Hurt E.M., Wiestner A., Rosenwald A. i wsp. Overexpression of cmaf is a frequent oncogenic event in multiple myeloma that promotes proliferation and pathological interactions with bone marrow stroma. Cancer Cell 2004; 5: 191-199.

72. Chesi M., Nardini E., Lim R.S. i wsp. The t(4;14) translocation in myeloma dysregulates both FGFR3 and a novel gene, MMSET, resulting in IgH/MMSET hybrid transcripts. Blood 1998; 92: 3025-3034.

73. Marango J., Shimoyama M., Nishio H. i wsp. The MMSET protein is a histone methyltransferase with characteristics of a transcriptional corepressor. Blood 2008; 111: 3145-3154.

74. Martinez-Garcia E., Popovic R., Min D.-J. i wsp. The MMSET histone methyl transferase switches global histone methylation and alters gene expression in $\mathrm{t}(4 ; 14)$ multiple myeloma cells. Blood 2011; 117: 211-220.

75. Kuo A.J., Cheung P., Chen K. i wsp. NSD2 links dimethylation of histone $\mathrm{H} 3$ at lysine 36 to oncogenic programming. Mol. Cell 2011; 44: 609-620.

76. Pei H., Zhang L., Luo K. i wsp. MMSET regulates histone H4K20 methylation and 53BP1 accumulation at DNA damage sites. Nature 2011; 470: 124-128.

77. Fonseca R., Debes-Marun C.S., Picken E.B. i wsp. The recurrent IgH translocations are highly associated with nonhyperdiploid variant multiple myeloma. Blood 2003; 102: 2562-2567.
78. Chapman M.A., Lawrence M.S., Keats J.J. i wsp. Initial genome sequencing and analysis of multiple myeloma. Nature 2011; 471 : 467-472.

79. Walker B.A., Leone P.E., Chiecchio L. i wsp. A compendium of myelomaassociated chromosomal copy number abnormalities and their prognostic value. Blood 2010; 116: e56-e65.

80. Walker B.A., Leone P.E., Jenner M.W. i wsp. Integration of global SNP-based mapping and expression arrays reveals key regions, mechanisms and genes important in the pathogenesis of multiple myeloma. Blood 2006; 108: 1733-1743.

81. Annunziata C.M., Davis R.E., Demchenko Y. i wsp. Frequent engagement of the classical and alternative $\mathrm{NF} \kappa \mathrm{B}$ pathways by diverse genetic abnormalities in multiple myeloma. Cancer Cell 2007; 12: 115-130.

82. Carrasco R., Tonon G., Brennan C. Comprehensive genome-wide profile of regional gains and losses in multiple myeloma using array-CGH: The 1q21 amplification and potential role of the BCL-9 gene in multiple myeloma pathogenesis. Blood 2004; 104: abstrakt 785.

83. Keats J.J., Fonseca R., Chesi M. i wsp. Promiscuous mutations activate the noncanonical $\mathrm{NF} \kappa \mathrm{B}$ pathway in multiple myeloma. Cancer Cell 2007; 12: 131-144.

84. Gonzalez-Paz N., Chng W.J., McClure R.F. i wsp. Tumor suppressor p16 methylation in multiple myeloma: biological and clinical implications. Blood 2007; 109: 1228-1232.

85. Affer M., Chesi M., Chen W.D. i wsp. Promiscuous MYC locus rearrangements hijack enhancers but mostly super-enhancers to dysregulate MYC expression in multiple myeloma. Leukemia 2014; 28: 1725-1735.

86. Chi P., Allis C.D., Wang G.G. Covalent histone modifications - miswritten, misinterpreted and miserased in human cancers. Nature Rev. Cancer 2010; 10: 457-469.

87. Walker B.A., Wardell C.P., Chiecchio L. i wsp. Aberrant global methylation patterns affect the molecular pathogenesis and prognosis of multiple myeloma. Blood 2011; 117: 553-562.

88. van Haaften G., Dalgliesh G.L., Davies H. i wsp. Somatic mutations of the histone H3K27 demethylase gene UTX in human cancer. Nat. Genet. 2009; 41: 521-523.

89. Aronson, L.I., Davenport E.L., Giuntoli S.G. i wsp. Autophagy is a key myeloma survival pathway that can be manipulated therapeutically to enhance apoptosis. Blood 2010; 116: abstrakt 4083.

90. Boyd K.D., Walker B.A., Wardell C.P. i wsp. High expression levels of the mammalian target of rapamycin inhibitor DEPTOR are predictive of response to thalidomide in myeloma. Leuk. Lymphoma 2010; 51: 2126-2129.

91. Boyd K.D., Ross F.M., Chiecchio L. i wsp. A novel prognostic model in myeloma based on co-segregating adverse FISH lesions and the ISS: analysis of patients treated in the MRC Myeloma IX trial. Leukemia 2012; 26: 349-355.

92. Ross F.M., Chiecchio L., Dagrada G. i wsp. The $t(14 ; 20)$ is a poor prognostic factor in myeloma but is associated with long-term stable disease in monoclonal gammopathies of undetermined significance. Haematologica 2010; 95: 1221-1225.

93. Boyd K.D., Ross F.M., Walker B.A. i wsp. Mapping of chromosome $1 p$ deletions in myeloma identifies FAM46C at 1p12 and CD$\mathrm{KN} 2 \mathrm{C}$ at $1 \mathrm{p} 32.3$ as being genes in regions associated with adverse survival. Clin. Cancer Res. 2011; 17: 7776-7784.

94. Boyd K.D., Ross F.M., Tapper W.J. i wsp. The clinical impact and molecular biology of del(17p) in multiple myeloma treated with 
conventional or thalidomide-based therapy. Genes Chromosomes Cancer 2011; 50: 765-774.

95. Kumar S., Fonseca R., Ketterling R.P. i wsp. Trisomies in multiple myeloma: impact on survival in patients with high-risk cytogenetics. Blood 2012; 119: 2100-2105.

96. Bolli N., Avet-Loiseau H., Wedge D.C. i wsp. Heterogeneity of genomic evolution and mutational profiles in multiple myeloma. Nat. Commun. 2014; 5: 2997.

97. Chapman M.A., Lawrence M.S., Keats J.J. i wsp. Initial genome sequencing and analysis of multiple myeloma. Nature 2011; 471: 467-472.

98. Nowell P.C. The clonal evolution of tumor cell populations. Science 1976 ; 194: 23-28.

99. Egan J.B., Shi C.X., Tembe W. i wsp. Whole-genome sequencing of multiple myeloma from diagnosis to plasma cell leukemia reveals genomic initiating events, evolution, and clonal tides. Blood 2012; 120: 1060-1066.

100. Morgan G.J., Walker B.A., Davies F.E. The genetic architecture of multiple myeloma. Nat. Rev. Cancer 2012; 12: 335-348.

101. Martinez-Lopez J., Fulciniti M., Barrio S. i wsp. Deep sequencing reveals oligoclonality at the immunoglobulin locus in multiple myeloma patients. Blood 2013; 122: abstrakt 401.

102. Keats J.J., Chesi M., Egan J.B. i wsp. Clonal competition with alternating dominance in multiple myeloma. Blood 2012; 120: 1067-1076.

103. Melchor L., Brioli A., Wardell C.P. i wsp. Single-cell genetic analysis reveals the composition of initiating clones and phylogenetic patterns of branching and parallel evolution in myeloma. Leukemia 2014; 28: 1705-1715.

104. Magrangeas F., Avet-Loiseau H., Gouraud W. i wsp. Minor clone provides a reservoir for relapse in multiple myeloma. Leukemia 2013; 27 : 473-481.

105. Walker B.A., Wardell C.P., Melchor L. i wsp. Intraclonal heterogeneity is a critical early event in the development of myeloma and precedes the development of clinical symptoms. Leukemia 2014; 28: 384-390.

106. De Raeve H.R., Vanderkerken K. The role of the bone marrow microenvironment in multiple myeloma. Histol. Histopathol. 2005; 20: 1227-1250.

107. Bolkun L., Lemancewicz D., Jablonska E. i wsp. BAFF and APRIL as TNF superfamily molecules and angiogenesis parallel progression of human multiple myeloma. Ann. Hematol. 2014; 93: 635-644.

108. Lichtenstein A., Tu Y., Fady C., Vescio R., Berenson J. Interleukin-6 inhibits apoptosis of malignant plasma cells. Cell. Immunol. 1995; 162: 248-255.

109. Schwarze M.M., Hawley R.G. Prevention of myeloma cell apoptosis by ectopic bcl-2 expression or interleukin 6-mediated up-regulation of bcl-xL. Cancer Res. 1995; 55: 2262-2265.

110. Børset M., Seidel C., Hjorth-Hansen H., Waage A., Sundan A. The role of hepatocyte growth factor and its receptor c-met in multiple myeloma and other blood malignancies. Leuk. Lymphoma 1999; 32: 249-256.

111. Hideshima T., Nakamura N., Chauhan D., Anderson H.C. The role of tumor necrosis factor $\alpha$ in the pathophysiology of human multiple myeloma: therapeutic applications. Oncogene 2001; 20: 4519-4527.

112. Derksen P.W.B., Keehnen R.M.J., Evers L.M. Cell surface proteoglycan syndecan-1 mediates hepatocyte growth factor binding and promotes Met signaling in multiple myeloma. Blood 2002; 99: 1405-1410.
113. Hideshima T., Bergsagel P.L., Kuehl W.M., Anderson K.C. Advances in biology of multiple myeloma: clinical applications. Blood 2004; 104: 607-618.

114. Hideshima T., Podar K., Chauhan D., Anderson K.C. Cytokines and signal transduction. Best Pract. Res. Clin. Haematol. 2005; 18: 509-524.

115. Peichev M., Naiyer A.J., Pereira D. i wsp. Expression of VEGFR-2 and AC133 by circulating human CD34+ cells identifies a population of functional endothelial precursors. Blood 2000; 95: 952-958.

116. Mitsiades C.S., Mitsiades N.S., Munshi N.C., Richardson P.G., Anderson K.C. The role of the bone microenvironment in the pathophysiology and therapeutic management of multiple myeloma: interplay of growth factors, their receptors and stromal interactions. Eur. J. Cancer 2006; 42: 1564-1573.

117. Coluccia A.M.L., Cirulli T., Neri P. i wsp. Validation of PDGFR $\beta$ and c-Src tyrosine kinases as tumor/vessel targets in patients with multiple myeloma: preclinical efficacy of the novel, orally available inhibitor dasatinib. Blood 2008; 112: 1346-1356.

118. Ribatti D., Vacca A., Nico B. i wsp. Bone marrow angiogenesis and mast cell density increase simultaneously with progression of human multiple myeloma. Br. J. Cancer 1999; 79: 451-455 .

119. Scavelli C., Nico B., Cirulli T. i wsp. Vasculogenic mimicry by bone marrow macrophages in patients with multiple myeloma. Oncogene 2008; 27: 663-674.

120. Cirri P., Chiarugi P. Cancer-associated fibroblasts and tumor cells: a diabolic liaison driving cancer progression. Cancer Metastasis Rev. 2012; 31: 195-208.

121. Frassanito M.A., Rao L., Moschetta M. Bone marrow fibroblasts parallel multiple myeloma progression in patients and mice: in vitro and in vivo studies. Leukemia 2014; 28: 904-916.

122. Cackowski F.C., Anderson J.L., Patrene K.D. i wsp. Osteoclasts are important for bone angiogenesis. Blood 2009; 115: 140 -149 .

123. Tanaka Y., Abe M., Hiasa M. i wsp. Myeloma cell-osteoclasts interaction enhances angiogenesis together with bone resorption: a role for vascular endothelial cell growth factor and osteopontin. Clin. Cancer Res. 2007; 13: 816-823.

124. Croucher P.I., De Hendrik R., Perry M.J. i wsp. Zoledronic acid treatment of 5T2MM-bearing mice inhibits the development of myeloma bone disease: evidence for decreased osteolysis, tumor burden and angiogenesis and increased survival. J. Bone Miner. Res. 2003; 18: 482-492.

125. Bataille R., Chappard D., Marcelli C. i wsp. Mechanisms of bone destruction in multiple myeloma: the importance of an unbalanced process in determining the severity of lytic bone disease. J. Clin. Oncol. 1989; 7: 1909-1914.

126. Roodman G.D. Pathogenesis of myeloma bone disease. Leukemia 2009; 23: 435-441.

127. Shaffer A.L., Shapiro-Shelef M., Iwakoshi N.N. i wsp. XBP1, downstream of Blimp-1, expands the secretory apparatus and other organelles, and increases protein synthesis in plasma cell differentiation. Immunity 2004; 21: 81-93.

128. Radbruch A., Muehlinghaus G., Luger E.O. i wsp. Competence and competition: the challenge of becoming a long-lived plasma cell. Nat. Rev. Immunol. 2006; 6: 741-750.

129. Avet-Loiseau H., Leleu X., Roussel M. i wsp. Bortezomib plus dexamethasone induction improves outcome of patients with $\mathrm{t}(4 ; 14)$ myeloma but not outcome of patients with del(17p). J. Clin. Oncol. 2010; 28: 4630-4634. 
130. Neben K., Lokhorst H.M., Jauch A. i wsp. Administration of bortezomib before and after autologous stem-cell transplantation improves outcome in multiple myeloma patients with deletion 17p. Blood 2012; 119: 940-948.

131. Cavo M., Pantani L., Petrucci M.T. i wsp. Bortezomib-thalidomide-dexamethasone is superior to thalidomide-dexamethasone as consolidation therapy after autologous hematopoietic stem cell transplantation in patients with newly diagnosed multiple myeloma. Blood 2012; 120: 9-19.

132. Morgan G.J., Davies F.E., Gregory W.M. i wsp. Cyclophosphamide, thalidomide, and dexamethasone (CTD) as initial therapy for patients with multiple myeloma unsuitable for autologous transplantation. Blood 2011; 118: 1231-1238.

133. Morgan G.J., Gregory W.M., Davies F.E. i wsp. The role of maintenance thalidomide therapy in multiple myeloma: MRC Myeloma IX results and meta-analysis. Blood 2012; 119: 7-15.
134. Avet-Loiseau H., Attal M., Moreau P. i wsp. Genetic abnormalities and survival in multiple myeloma: the experience of the Intergroupe Francophone du Myelome. Blood 2007; 109: 3489-3495.

135. Avet-Loiseau H., Li C., Magrangeas F. i wsp. Prognostic significance of copynumber alterations in multiple myeloma. J. Clin. Oncol. 2009; 27: 4585-4590.

136. Paiva B., Gutiérrez N.C., Rosiñol L. i wsp. High-risk cytogenetics and persistent minimal residual disease by multiparameter flow cytometry predict unsustained complete response after autologous stem cell transplantation in multiple myeloma. Blood 2012; 119: 687-691.

137. Andrulis M., Lehners N., Capper D. i wsp. Targeting the BRAF V600E mutation in multiple myeloma. Cancer Discov. 2013; 3: 862-869. 